Article

\title{
Phase Equilibria and Magnetic Phases in the Ce-Fe-Co-B System
}

\author{
Tian Wang ${ }^{1}$, Dmytro Kevorkov ${ }^{1}$ and Mamoun Medraj ${ }^{1,2, *}$ \\ 1 Department of Mechanical and Industrial Engineering, Concordia University, \\ 1455 de Maisonneuve Boulevard West, Montreal, QC H3G 1M8, Canada; \\ wa_ti@encs.concordia.ca (T.W.); dmytro.kevorkov@gmail.com (D.K.) \\ 2 Department of Mechanical and Materials Engineering, Masdar Institute, Masdar City P.O. Box 54224, \\ Abu Dhabi, United Arab Emirates \\ * Correspondence: mmedraj@encs.concordia.ca; Tel.: +1-514-848-2424 (ext. 3146)
}

Academic Editor: Sofoklis Makridis

Received: 3 November 2016; Accepted: 20 December 2016; Published: 28 December 2016

\begin{abstract}
Ce-Fe-Co-B is a promising system for permanent magnets. A high-throughput screening method combining diffusion couples, key alloys, Scanning Electron Microscope/Wavelength Dispersive X-ray Spectroscope (SEM/WDS), and Magnetic Force Microscope (MFM) is used in this research to understand the phase equilibria and to explore promising magnetic phases in this system. Three magnetic phases were detected and their homogeneity ranges were determined at $900{ }^{\circ} \mathrm{C}$, which were presented by the formulae: $\mathrm{Ce}_{2} \mathrm{Fe}_{14-x} \mathrm{Co}_{x} \mathrm{~B}(0 \leq x \leq 4.76), \mathrm{CeCo}_{4-x} \mathrm{Fe}_{x} \mathrm{~B}$ $(0 \leq x \leq 3.18)$, and $\mathrm{Ce}_{3} \mathrm{Co}_{11-x} \mathrm{Fe}_{x} \mathrm{~B}_{4}(0 \leq x \leq 6.66)$. The phase relations among the magnetic phases in this system have been studied. $\mathrm{Ce}_{2}(\mathrm{Fe}, \mathrm{Co})_{14} \mathrm{~B}$ appears to have stronger magnetization than $\mathrm{Ce}(\mathrm{Co}, \mathrm{Fe})_{4} \mathrm{~B}$ and $\mathrm{Ce}_{3}(\mathrm{Co}, \mathrm{Fe})_{11} \mathrm{~B}_{4}$ from MFM analysis when comparing the magnetic interactions of selected key alloys. Also, a non-magnetic $\mathrm{CeCo}_{12-x} \mathrm{Fe}_{x} \mathrm{~B}_{6}(0 \leq x \leq 8.74)$ phase was detected in this system. A boron-rich solid solution with $\mathrm{Ce}_{13} \mathrm{Fe}_{x} \mathrm{Co}_{y} \mathrm{~B}_{45}(32 \leq x \leq 39,3 \leq y \leq 10)$ chemical composition was also observed. However, the crystal structure of this phase could not be found in the literature. Moreover, ternary solid solutions $\varepsilon_{1}\left(\mathrm{Ce}_{2} \mathrm{Fe}_{17-x} \mathrm{Co}_{x}(0 \leq x \leq 12.35)\right)$ and $\varepsilon_{2}\left(\mathrm{Ce}_{2} \mathrm{Co}_{17-x} \mathrm{Fe}_{x}\right.$ $(0 \leq x \leq 3.57))$ were found to form between $\mathrm{Ce}_{2} \mathrm{Fe}_{17}$ and $\mathrm{Ce}_{2} \mathrm{Co}_{17}$ in the Ce-Fe-Co ternary system at $900{ }^{\circ} \mathrm{C}$
\end{abstract}

Keywords: phase equilibria; Ce-Fe-Co-B quaternary system; magnetic phases; MFM; SEM/WDS

\section{Introduction}

Manufacturing of hybrid and electric cars has escalated the need for strong and inexpensive permanent magnets. Modern permanent magnets devices require the presence of large coercivity. Among different commercial permanent magnets, rare-earth-based materials have been considered as the most favorable candidates due to their suitable magnetic properties [1]. The growing world demand for permanent magnets and rising costs of $\mathrm{Nd}$ and other less abundant rare earth metals (e.g., Sm and Dy) necessitates the development of new Fe-based magnets with the addition of relatively abundant inexpensive rare earth metals (e.g., Ce). Despite the low Curie temperature, $\mathrm{Ce}_{2} \mathrm{Fe}_{14} \mathrm{~B}$ was found to have suitable magnetic properties and could possibly be used in the industry [2]. Co was recognized as a potential additive to increase Curie temperature of $\mathrm{Ce}_{2} \mathrm{Fe}_{14} \mathrm{~B}$ [3]. Thus, the Ce-Fe-Co-B quaternary system is a promising system for magnetic materials with suitable magnetic properties as well as low cost for the automotive or electromechanical applications, especially in the Fe-rich region. Knowledge of phase equilibria is necessary for magnetic materials development and for the optimization of magnets composition as well as establishing the heat-treatment conditions. However, limited experimental results can be found in the literature regarding this system. In this research, 
phase equilibria in the Ce-Fe-Co-B system are investigated. For this purpose and to find promising magnetic compounds, a high-throughput screening (HTS) method is adopted.

\section{Literature Review}

\subsection{Ternary Systems}

The Ce-Fe-Co-B system consists of $\mathrm{Ce}-\mathrm{Fe}-\mathrm{B}, \mathrm{Co}-\mathrm{Fe}-\mathrm{B}, \mathrm{Ce}-\mathrm{Co}-\mathrm{B}$, and $\mathrm{Ce}-\mathrm{Fe}-\mathrm{Co}$ four sub-ternary systems. The phase equilibria in $\mathrm{Ce}-\mathrm{Fe}-\mathrm{B}, \mathrm{Co}-\mathrm{Fe}-\mathrm{B}$, and $\mathrm{Ce}-\mathrm{Co}-\mathrm{B}$ were established or partially established in the literature. A number of ternary compounds have been found among these three systems. However, there are still some questionable and uncertain phase relationships in the Ce-Fe-Co system which will be described in the coming section. A brief literature review regarding all the constituent ternary systems is included below.

The phase diagram of the Ce-Fe-B system was investigated by several researchers [4-7]. Raghavan [8] summarized the previous works and re-drew the isothermal section at $700{ }^{\circ} \mathrm{C}$, as shown in Figure 1. As can be seen from this figure, three ternary compounds, $\mathrm{Ce}_{2} \mathrm{Fe}_{14} \mathrm{~B}, \mathrm{CeFe}_{4} \mathrm{~B}_{4}$, and $\mathrm{Ce}_{5} \mathrm{Fe}_{2} \mathrm{~B}_{6}$, were reported.

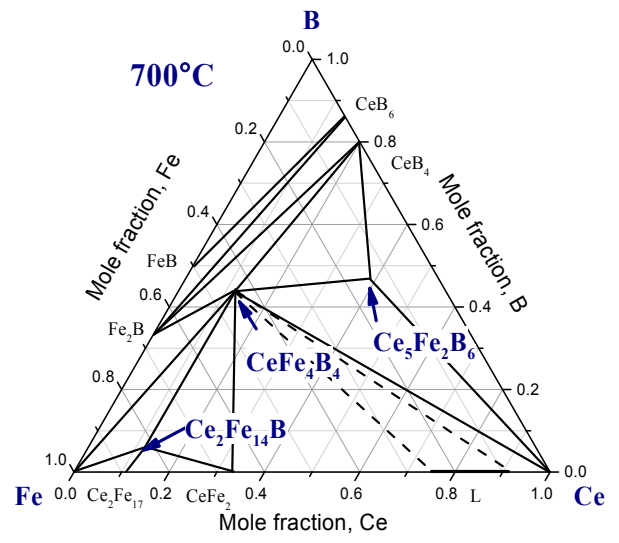

Figure 1. Isothermal section of $\mathrm{Ce}-\mathrm{Fe}-\mathrm{B}$ system at $700{ }^{\circ} \mathrm{C}[8]$.

The early experimental studies of the Co-Fe-B ternary system can be found in [9-11]. Liu et al. [12] calculated isothermal sections of this system at $900{ }^{\circ} \mathrm{C}$ and $1000^{\circ} \mathrm{C}$. Their results were in reasonable agreement with the experimental data provided by Van Loo et al. [11] at $900{ }^{\circ} \mathrm{C}$ as shown in Figure 2a. At $1000{ }^{\circ} \mathrm{C}$, the experimental data provided by Liu et al. [12] and Rogl et al. [9] contradicted those reported by of Pradelli et al. [10], as can be seen from Figure 2b.

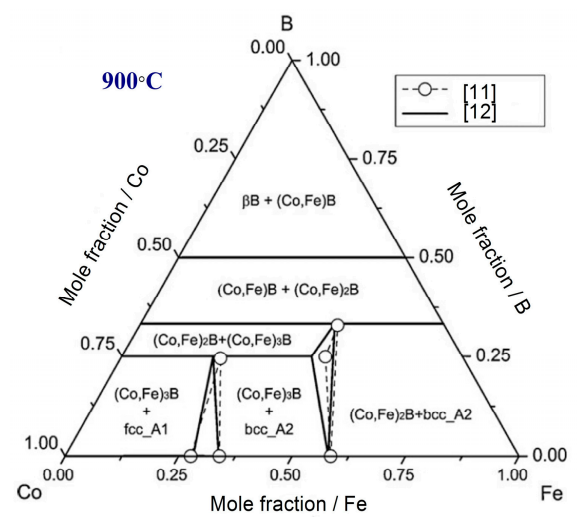

(a)

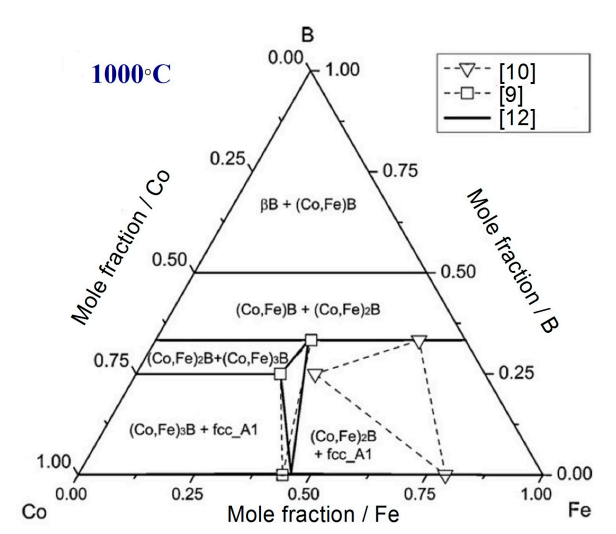

(b)

Figure 2. Isothermal section of Co-Fe-B ternary system at (a) $900{ }^{\circ} \mathrm{C}$ [12]; and (b) $1000{ }^{\circ} \mathrm{C}$ [12]. 
Two partial isothermal sections of Ce-Co-B were reported by Bilonizhko et al. [13], as shown in Figure 3. Thirteen ternary compounds $\left(\mathrm{B}_{2} \mathrm{CeCo}_{3}, \mathrm{~B}_{3} \mathrm{CeCo}_{8}, \mathrm{BCeCo}, \mathrm{BCe}_{2} \mathrm{Co}_{4}, \mathrm{BCeCo}_{4}, \mathrm{~B}_{3} \mathrm{Ce}_{2} \mathrm{Co}_{7}\right.$, $\mathrm{B}_{4} \mathrm{CeCo}_{4}, \mathrm{~B}_{4} \mathrm{Ce}_{3} \mathrm{Co}_{11}, \mathrm{BCe}_{2} \mathrm{Co}_{3}, \mathrm{BCeCo}_{2}, \mathrm{~B}_{4} \mathrm{CeCo}, \mathrm{B}_{3} \mathrm{CeCo}$, and $\mathrm{B}_{2} \mathrm{Ce}_{2} \mathrm{Co}$ ) were found. It was reported that $\mathrm{BCeCo}$ is a high-temperature compound that formed at $800{ }^{\circ} \mathrm{C}$ and decomposed at $400{ }^{\circ} \mathrm{C}$. Therefore, BCeCo can be seen only in Figure 3a, not in Figure 3b. Later, four additional ternary compounds were reported: $\mathrm{B}_{2} \mathrm{Ce}_{2} \mathrm{Co}_{5}[14], \mathrm{BCe}_{3} \mathrm{Co}_{20}$ [15], $\mathrm{B}_{6} \mathrm{CeCo}_{12}$ [16], and $\mathrm{B}_{6} \mathrm{Ce}_{5} \mathrm{Co}_{2}$ [17]. However, the thermal stability of these compounds and their phase relationships are still unknown. Having sixteen ternary compounds makes B-Ce-Co a very complex system. Therefore, a significant amount of experimental and thermodynamic modeling research on this system is still needed.

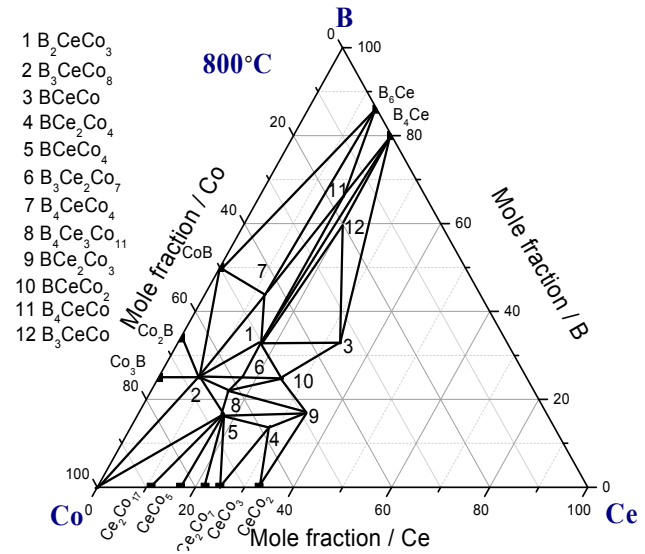

(a)

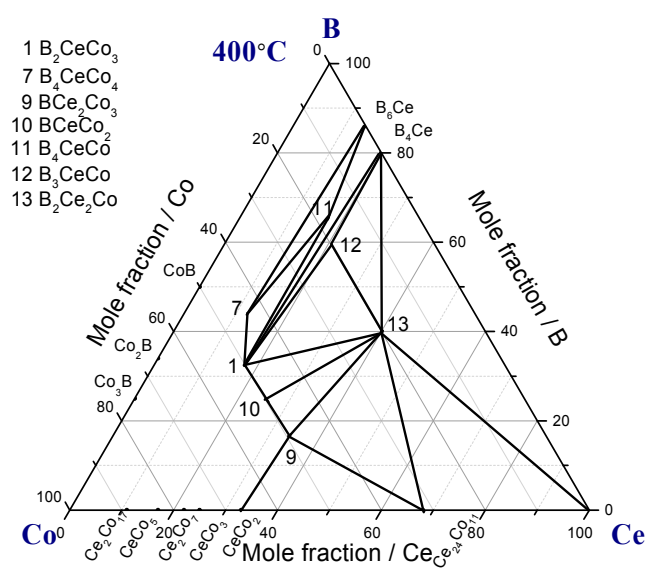

(b)

Figure 3. Isothermal section of B-Ce-Co ternary system at (a) $800{ }^{\circ} \mathrm{C}$ and (b) $400{ }^{\circ} \mathrm{C}$ redrawn from [13].

The literature data on the experimental phase equilibria in the Ce-Co-Fe ternary system is limited to the work of Critchley [18], who reported a partial liquidus projection (Figure 4a) and partial triangulation of the isothermal section at $450{ }^{\circ} \mathrm{C}$ (Figure $4 \mathrm{~b}$ ). These figures were re-drawn from the ASM Alloy Phase Diagram Database [19]. It should be mentioned that the triangulation of the $\mathrm{L}+\mathrm{Ce}+\mathrm{CeFe}_{2}$ three-phase region in Figure $4 \mathrm{~b}$ is incorrect, because $\mathrm{CeFe}_{2}$ compound must not extend beyond 33 at. \% Ce at the Ce-Fe side, according to the chemical composition of the compound. Also, the liquid region in the Ce-Co system should be limited to the range of $22-34$ at. \% Co, based on the most recent Ce-Co binary phase diagram [20]. Moreover, Mansey et al. [21] studied the change of lattice parameters of the $\mathrm{CeFe}_{2}-\mathrm{CeCo}_{2}$ quasi-binary section. They reported a continuous solid solubility between the $\mathrm{CeFe}_{2}$ and $\mathrm{CeCo}_{2}$ compounds. These results were confirmed later by Harris and Longworth [22], and Longworth and Harris [23], who reported that the $\mathrm{CeFe}_{2}-\mathrm{CeCo}_{2}$ solid solution at $1173 \mathrm{~K}$ has a cubic $\mathrm{C} 15$ Laves phase. In this ternary system, the phase equilibria in the Co-Fe side is still unclear. Especially, the phase relationships between $\mathrm{Ce}_{2} \mathrm{Co}_{17}$ and $\mathrm{Ce}_{2} \mathrm{Fe}_{17}$ are missing in the literature. These two compounds are isostructural compounds with a hexagonal $\mathrm{Th}_{2} \mathrm{Zn}_{17}$ crystal structure prototype [24]. Therefore, they are expected to form a continuous solid solution. 


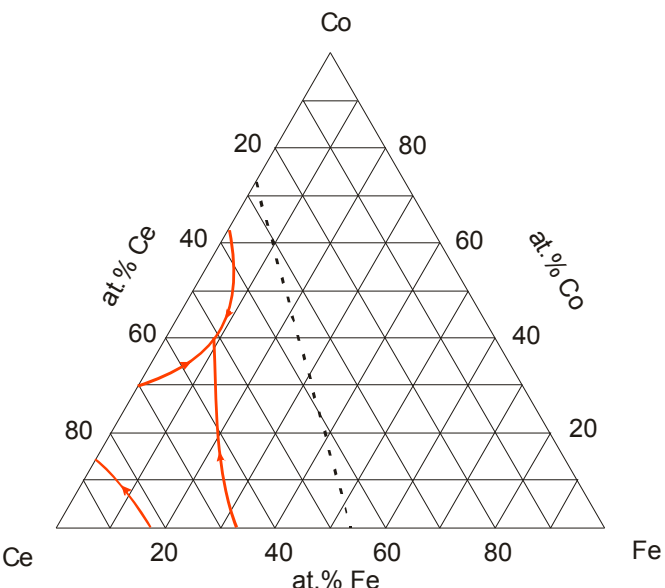

(a)

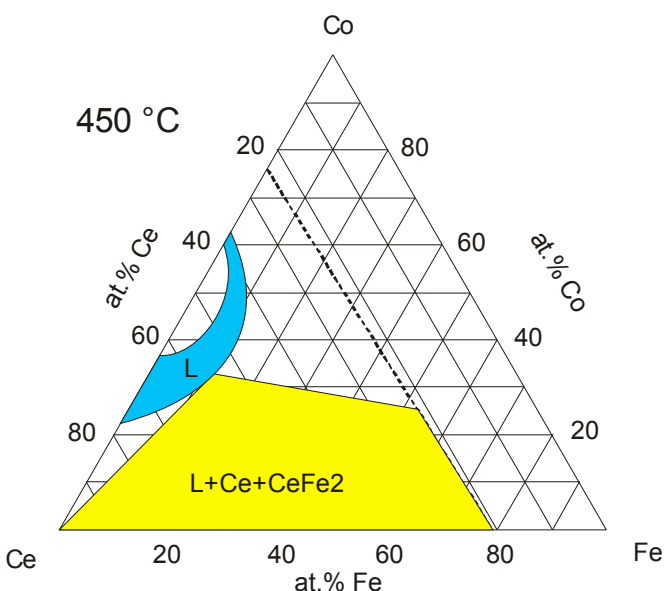

(b)

Figure 4. (a) Partial liquidus projection of Ce-Co-Fe system [18]; (b) partial isothermal section of Ce-Co-Fe system at $450{ }^{\circ} \mathrm{C}$ [18].

\subsection{Quaternary System}

Limited experimental results regarding the phase equilibria in the $\mathrm{Ce}-\mathrm{Fe}-\mathrm{Co}-\mathrm{B}$ system can be found in the literature. Skoug et al. [3] reported two series of $\mathrm{Ce}_{3} \mathrm{Fe}_{14-} \mathrm{Co}_{x} \mathrm{~B}$ and $\mathrm{Ce}_{2.55} \mathrm{Fe}_{14-} \mathrm{Co}_{x} \mathrm{~B}_{1.27}$ melt-spun ribbons and their magnetic properties were also studied. Co was found to dissolve in $\mathrm{Ce}_{2} \mathrm{Fe}_{14} \mathrm{~B}$ and form magnetic $\mathrm{Ce}_{2}(\mathrm{Fe}, \mathrm{Co})_{14} \mathrm{~B}$ compound. However, the maximum solid solubility of $\mathrm{Ce}_{2}(\mathrm{Fe}, \mathrm{Co})_{14} \mathrm{~B}$ is still unknown, and the phase relationships need to be understood. Also, the presence of other magnetic phases in this system should be verified. Thus, it is necessary to carry out research to understand the phase equilibria as well as to screen other promising magnetic phases in the Ce-Fe-Co-B system.

\section{Materials and Methods}

By combining diffusion couples and key alloys, with the aid of the Scanning Electron Microscope (SEM) and Magnetic Force Microscope (MFM), the HTS method is much more efficient to understand the phase equilibria and to screen magnetic compounds in a multi-component system. HTS is used to screen magnetic phases in the $\mathrm{Ce}-\mathrm{Fe}-\mathrm{Co}-\mathrm{B}$ multi-component system combining microstructural, micro-elemental, and magnetic domain analyses of diffusion couples and key alloys. Magnetic phases could be identified through their domain interactions with the magnetic tip of the MFM. The analysis of one successful diffusion couple can potentially give complete information on a large number of intermetallic phases in the system at a specific temperature. Based on the diffusion couples results, key alloys are prepared and studied further by X-ray Diffraction (XRD) for phase identification and MFM to confirm the presence of a magnetic phase in a significant amount. Importantly, the key alloys can be used to measure intrinsic magnetic properties, such as saturation magnetization, anisotropy fields, and Curie temperature. These properties for $\mathrm{Ce}_{2} \mathrm{Fe}_{14} \mathrm{~B}$ modified by $\mathrm{Co}$ will be reported in another paper. HTS significantly reduces the number of experiments and the timeframe. However, ternary or quaternary diffusion couples have unpredictable diffusion paths, which could lead to omitting some phases. Besides, slow kinetic formation of some phases may cause the formation of thin layers that might be difficult to be successfully analyzed [25]. Therefore, key alloys are used to verify the results obtained from diffusion couples. In this study, four solid-state diffusion couples and fifteen key alloys were prepared. Pure materials with $99 \mathrm{wt}$. \% purity or better are used as the starting materials. All the elements are supplied by Alfa Aesar ${ }^{\circledR}$ (Haverhill, MA, USA), Johnson Matthey Company (London, UK). Samples of known composition are prepared from pure metals using an arc melting furnace under argon atmosphere. 
The arc melting furnace is equipped with a water-cooled copper crucible and a non-consumable tungsten electrode. Every alloy must be melted several times to ensure homogeneity. The prepared samples were used as key alloys or as end-members for the diffusion-couple experiments. Diffusion couples were prepared by grinding down the contacting interfaces of end-members using 1200 grit $\mathrm{SiC}$ paper and then polished up to $1 \mu \mathrm{m}$ using alcohol-based diamond suspension. Ninety-nine per cent pure ethanol was used as lubricant. The selected end-members were carefully pressed and clamped together using a stainless steel ring. For the annealing process, samples were encapsulated inside quartz tubes under vacuum. After sufficient annealing time (at least 25 days), samples were quenched in a cold water bath to obtain the high-temperature structure. Quenched samples or diffusion couples were polished and grinded up to $1 \mu \mathrm{m}$ in order to be analyzed using SEM coupled with Energy/Wavelength Dispersive X-ray Spectroscopes (EDS/WDS) and MFM. The microstructure and phase composition of the samples were analyzed by SEM/WDS (HITACHI S-3400N, HITACHI, Tokyo, Japan). XRD was performed for the key alloys using PANAnalytical Xpert Pro X-ray diffractometer (PANAnalytical, Almelo, The Netherlands) with a CuK $\alpha$ radiation at $45 \mathrm{kV}$ and $40 \mathrm{~mA}$. XRD patterns were analyzed using X'Pert Highscore plus software [26] and the Rietveld method. The crystal structure prototypes of the detected phases were obtained from Pearson's Database [24] and used in XRD analysis. Quenched samples were also used for MFM imaging using Digital Instruments Multimode Atomic Force Microscope (Digital Instruments, Billerica, MA, USA) in LiftMode. In this work, a $225 \mu \mathrm{m}$ long silicon cantilever having a magnetic pyramidal tip was used to acquire the magnetic gradient images. The MFM tip, supplied by Appnano Ltd. (Mountain View, CA, USA) was coated with an approximately $50 \mathrm{~nm}$ CoCr layer. The cantilevers have resonant frequency between 47 and $76 \mathrm{kHz}$. This frequency is shifted by an amount proportional to the vertical gradient of the magnetic forces on the tip [27]. The frequency shifts can be detected by the phase detection capability of the MFM. The drive frequency of the cantilever for the phase detection was set to be the center of the cantilever resonance. The signal was measured as the cantilever's phase of oscillation relative to the piezo drive. And the magnetic contrast can be achieved through the magnetostatic interaction between the MFM tip and the stray fields from the sample [27]. When attractive interactions occur, negative phase shift and dark image contrast can be observed in the MFM images. Whereas, positive phase shift and bright image contrast result when repulsive interactions take place [27].

\section{Results and Discussion}

\subsection{Diffusion Couples Results}

In order to understand the phase equilibria in the Ce-Fe-Co-B system, four diffusion couples were prepared. The chemical compositions across the diffusion couples and the corresponding phases that formed in the diffusion layers are listed in Table 1. Diffusion couples were all annealed at $900{ }^{\circ} \mathrm{C}$ for 4 weeks.

The backscattered electron (BSE) image of DC1 is presented in Figure 5a. As a result of diffusion between $\mathrm{Ce}_{2} \mathrm{Fe}_{14} \mathrm{~B}$ and $\mathrm{Co}$, six diffusion layers formed. The compositions of the formed phases were determined using WDS point analysis. The solubility ranges were measured by WDS line scan. In the first layer, the end-member $\mathrm{Ce}_{2} \mathrm{Fe}_{14} \mathrm{~B}$ (white) was in equilibrium with the $\alpha$-(Fe, $\mathrm{Co}$ ) phase (black). Fe was substituted by $\mathrm{Co}$ in both phases during the diffusion process. A WDS compositional profile of $\mathrm{Ce}_{2}(\mathrm{Fe}, \mathrm{Co})_{14} \mathrm{~B}$ is shown in Figure $5 \mathrm{~b}$. The quaternary solid solubility of $\mathrm{Ce}_{2} \mathrm{Fe}_{14} \mathrm{~B}$ was determined as 9 at. \% $\mathrm{Co}$, which was presented by the formula $\mathrm{Ce}_{2} \mathrm{Fe}_{14-x} \mathrm{Co}_{x} \mathrm{~B}$ $(0 \leq x \leq 1.54)$. Co in $\alpha$-Fe in layer 1 was found to be 6 at. $\%$. The grey phase in layer 2 was identified as $\mathrm{Ce}_{2}(\mathrm{Fe}, \mathrm{Co})_{17}$ with $\mathrm{Ce}_{11} \mathrm{Fe}_{34-79} \mathrm{Co}_{10-55}$ composition and named as $\varepsilon_{1}$ in this study. The WDS compositional profile of $\mathrm{Ce}_{2}(\mathrm{Fe}, \mathrm{Co})_{17}$ is plotted in Figure $5 \mathrm{c}$. At the boundary between layers 1 and 2, three phase equilibrium $\left(\mathrm{Ce}_{2}(\mathrm{Fe}, \mathrm{Co})_{14} \mathrm{~B} / \alpha-(\mathrm{Fe}, \mathrm{Co}) / \varepsilon_{1}\right)$ was observed. Moreover, the concentration of Co dissolved in $\alpha$-Fe phase (black) also gradually increased from 6 to 44 at. $\%$ in layer 2 . White phase in layer 3 was found to be a stoichiometric compound with $\mathrm{Ce}_{16} \mathrm{Fe}_{9} \mathrm{Co}_{59} \mathrm{~B}_{16}$ composition. This new 
quaternary compound is in equilibrium with $\alpha-(\mathrm{Fe}, \mathrm{Co})$ (black) and had similar composition to $\mathrm{CeCo}_{4} \mathrm{~B}$, considering the Fe-Co substitution which was also confirmed by key alloys. A three-phase region was established between $\varepsilon_{1}, \alpha-(\mathrm{Fe}, \mathrm{Co})$, and $\mathrm{Ce}(\mathrm{Co}, \mathrm{Fe})_{4} \mathrm{~B}$. Co-rich $\mathrm{Ce}_{2}(\mathrm{Co}, \mathrm{Fe})_{17}$ with $\mathrm{Ce}_{11} \mathrm{Fe}_{19} \mathrm{Co}_{70}$ chemical composition was detected in layer 4 , where it is in equilibrium with $\alpha-(\mathrm{Fe}, \mathrm{Co})$. Substitution of Fe by $\mathrm{Co}$ was found to be up to 61 at. \%. Another three-phase region was obtained among $\alpha-(\mathrm{Fe}, \mathrm{Co})$, $\mathrm{Ce}(\mathrm{Co}, \mathrm{Fe})_{4} \mathrm{~B}$, and $\mathrm{Ce}_{2}(\mathrm{Co}, \mathrm{Fe})_{17}$. Through WDS analysis, layer 5 has been analyzed as $\alpha-(\mathrm{Fe}, \mathrm{Co})$ and its homogeneity range was measured as $65-70$ at. \% Co. The dominating black phase in the thin layer 6 was determined to be $\gamma-(\mathrm{Fe}, \mathrm{Co})$ with a relatively small amount of $\mathrm{Fe}$ of about $8-12$ at. \%. This phase is in equilibrium with $\mathrm{Ce}_{2}(\mathrm{Co}, \mathrm{Fe})_{17}$ (white), which was measured to have $\mathrm{Ce}_{11} \mathrm{Fe}_{2} \mathrm{Co}_{87}$ chemical composition. This two-phase equilibrium is also confirmed by DC2.

Table 1. Chemical compositions across the diffusion couples and the corresponding phases.

\begin{tabular}{|c|c|c|c|c|c|c|}
\hline \multirow{2}{*}{ Diffusion Couple } & \multirow{2}{*}{ Layer } & \multicolumn{4}{|c|}{ Composition (at. \%) } & \multirow{2}{*}{ Corresponding Phase } \\
\hline & & $\mathrm{Ce}$ & $\mathrm{Fe}$ & Co & B & \\
\hline \multirow{11}{*}{$\mathrm{DC} 1\left(\mathrm{Ce}_{2} \mathrm{Fe}_{14} \mathrm{~B} / \mathrm{Co}\right)$} & \multirow{2}{*}{1} & 12 & $82-73$ & $0-9$ & 6 & \multirow{2}{*}{$\begin{array}{c}\mathrm{Ce}_{2}(\mathrm{Fe}, \mathrm{Co})_{14} \mathrm{~B} \\
\alpha-(\mathrm{Fe}, \mathrm{Co})\end{array}$} \\
\hline & & 0 & 100-93 & $0-7$ & 0 & \\
\hline & \multirow{2}{*}{2} & 11 & $79-34$ & $10-55$ & 0 & \multirow{2}{*}{$\begin{array}{c}\mathrm{Ce}_{2}(\mathrm{Fe}, \mathrm{Co})_{17} \\
\alpha-(\mathrm{Fe}, \mathrm{Co})\end{array}$} \\
\hline & & 0 & $93-57$ & $7-43$ & 0 & \\
\hline & \multirow{2}{*}{3} & 16 & 9 & 59 & 16 & \multirow{2}{*}{$\begin{array}{c}\mathrm{Ce}(\mathrm{Co}, \mathrm{Fe})_{4} \mathrm{~B} \\
\alpha-(\mathrm{Fe}, \mathrm{Co})\end{array}$} \\
\hline & & 0 & $57-39$ & $43-61$ & 0 & \\
\hline & \multirow{2}{*}{4} & 11 & 19 & 70 & 0 & \multirow{2}{*}{$\begin{array}{c}\mathrm{Ce}_{2}(\mathrm{Co}, \mathrm{Fe})_{17} \\
\alpha-(\mathrm{Fe}, \mathrm{Co})\end{array}$} \\
\hline & & 0 & 39 & 61 & 0 & \\
\hline & 5 & 0 & $35-30$ & $65-70$ & 0 & $\alpha-(\mathrm{Fe}, \mathrm{Co})$ \\
\hline & \multirow[b]{2}{*}{6} & 0 & 12 & 88 & 0 & $\gamma-(\mathrm{Fe}, \mathrm{Co})$ \\
\hline & & 11 & 2 & 87 & 0 & $\mathrm{Ce}_{2}(\mathrm{Co}, \mathrm{Fe})_{17}$ \\
\hline \multirow{9}{*}{$\begin{array}{c}\mathrm{DC} 2 \\
\left(\mathrm{Ce}_{13} \mathrm{Fe}_{80} \mathrm{~B}_{7} / \mathrm{Co}_{90} \mathrm{Ce}_{10}\right)\end{array}$} & \multirow{2}{*}{1} & 12 & $82-60$ & $0-22$ & 6 & \multirow{2}{*}{$\begin{array}{c}\mathrm{Ce}_{2}(\mathrm{Fe}, \mathrm{Co})_{14} \mathrm{~B} \\
\alpha-(\mathrm{Fe}, \mathrm{Co})\end{array}$} \\
\hline & & 0 & $100-82$ & $0-18$ & 0 & \\
\hline & \multirow{2}{*}{2} & 15 & $27-17$ & $42-52$ & 16 & \multirow{3}{*}{$\begin{array}{c}\mathrm{Ce}(\mathrm{Co}, \mathrm{Fe})_{4} \mathrm{~B} \\
\alpha-(\mathrm{Fe}, \mathrm{Co}) \\
\alpha-(\mathrm{Fe}, \mathrm{Co})\end{array}$} \\
\hline & & 0 & $82-37$ & $18-63$ & 0 & \\
\hline & 3 & 0 & $35-33$ & $65-67$ & 0 & \\
\hline & \multirow[b]{2}{*}{4} & 16 & $6-1$ & $63-68$ & 15 & $\mathrm{Ce}(\mathrm{Co}, \mathrm{Fe})_{4} \mathrm{~B}$ \\
\hline & & 11 & 14 & 75 & 0 & \multirow{3}{*}{$\begin{array}{c}\mathrm{Ce}_{2}(\mathrm{Co}, \mathrm{Fe})_{17} \\
\gamma-(\mathrm{Fe}, \mathrm{Co}) \\
\mathrm{Ce}_{2}(\mathrm{Co}, \mathrm{Fe})_{17}\end{array}$} \\
\hline & \multirow{2}{*}{5} & 0 & $11-0$ & 89-100 & 0 & \\
\hline & & 11 & $14-0$ & $75-89$ & 0 & \\
\hline \multirow{7}{*}{$\begin{array}{c}\mathrm{DC} 3 \\
\left(\mathrm{Ce}_{10} \mathrm{Fe}_{75} \mathrm{~B}_{15} / \mathrm{Co}\right)\end{array}$} & \multirow{3}{*}{1} & 12 & $82-65$ & $0-17$ & 6 & \multirow{2}{*}{$\begin{array}{c}\mathrm{Ce}_{2}(\mathrm{Fe}, \mathrm{Co})_{14} \mathrm{~B} \\
\alpha-(\mathrm{Fe}, \mathrm{Co})\end{array}$} \\
\hline & & 0 & $100-70$ & $0-30$ & 0 & \\
\hline & & 13 & 38 & 4 & 45 & $\mathrm{Ce}_{13} \mathrm{Fe}_{38} \mathrm{Co}_{4} \mathrm{~B}_{45}$ \\
\hline & \multirow{2}{*}{2} & 16 & $21-5$ & $40-56$ & 23 & \multirow{4}{*}{$\begin{array}{c}\mathrm{Ce}_{3}(\mathrm{Co}, \mathrm{Fe})_{11} \mathrm{~B}_{4} \\
\alpha-(\mathrm{Fe}, \mathrm{Co}) \\
\mathrm{Ce}(\mathrm{Co}, \mathrm{Fe})_{12} \mathrm{~B}_{5} \\
\alpha-(\mathrm{Fe}, \mathrm{Co})\end{array}$} \\
\hline & & 0 & $70-44$ & $30-56$ & 0 & \\
\hline & 3 & 6 & 11 & 53 & 30 & \\
\hline & 4 & 0 & $33-30$ & $67-70$ & 0 & \\
\hline & & 16 & $45-40$ & $23-28$ & 16 & $\mathrm{Ce}(\mathrm{Co}, \mathrm{Fe})_{4} \mathrm{~B}$ \\
\hline & 1 & 0 & 17 & 83 & 0 & $\alpha-(\mathrm{Fe}, \mathrm{Co})$ \\
\hline & & 13 & 32 & 10 & 45 & $\mathrm{Ce}_{13} \mathrm{Fe}_{32} \mathrm{Co}_{10} \mathrm{~B}_{45}$ \\
\hline & & 17 & $23-9$ & $37-51$ & 23 & $\mathrm{Ce}_{3}(\mathrm{Co}, \mathrm{Fe})_{11} \mathrm{~B}_{4}$ \\
\hline$\left(\mathrm{Ce}_{15} \mathrm{Fe}_{43} \mathrm{Co}_{19} \mathrm{~B}_{32} / \mathrm{Co}\right)$ & 2 & 0 & $65-53$ & $35-47$ & 0 & $\alpha-(\mathrm{Fe}, \mathrm{Co})$ \\
\hline$\left(\mathrm{Ce}_{15} \mathrm{Fe}_{43} \mathrm{Co}_{19} \mathrm{~B}_{23} / \mathrm{Co}\right)$ & & 6 & $18-9$ & $46-55$ & 30 & $\mathrm{Ce}(\mathrm{Co}, \mathrm{Fe})_{12} \mathrm{~B}_{5}$ \\
\hline & 3 & 0 & 53 & 47 & 0 & $\alpha-(\mathrm{Fe}, \mathrm{Co})$ \\
\hline & 4 & 0 & 31 & 69 & 0 & $\alpha-(\mathrm{Fe}, \mathrm{Co})$ \\
\hline & 5 & 0 & $14-11$ & $86-89$ & 0 & $\gamma-(\mathrm{Fe}, \mathrm{Co})$ \\
\hline
\end{tabular}

The experimental results of DC1 are summarized in the 3D view, as shown in Figure 6a. The phases which were detected in this diffusion couple are denoted by different colors. The $\varepsilon_{1}$ and $\alpha-(\mathrm{Fe}, \mathrm{Co})$ are illustrated on the Fe-Co-Ce ternary system in Figure 6b. Two pseudo ternary sections at 12 at. \% and 16 at. \% Ce are plotted in Figure $6 c, d$ to enable better understanding of the phase relations in 
DC1. The phase relations obtained from DC1 are summarized in Figure 6e. Three three-phase regions, $\mathrm{Ce}_{2}(\mathrm{Fe}, \mathrm{Co})_{14} \mathrm{~B} / \alpha-(\mathrm{Fe}, \mathrm{Co}) / \varepsilon_{1}, \alpha-(\mathrm{Fe}, \mathrm{Co}) / \varepsilon_{1} / \mathrm{Ce}(\mathrm{Co}, \mathrm{Fe})_{4} \mathrm{~B}$, and $\mathrm{Ce}(\mathrm{Co}, \mathrm{Fe})_{4} \mathrm{~B} / \alpha-(\mathrm{Fe}, \mathrm{Co}) / \mathrm{CeFe}_{2} \mathrm{Co}_{7}$, are established at the interfaces from layers $1-4$ of DC1.

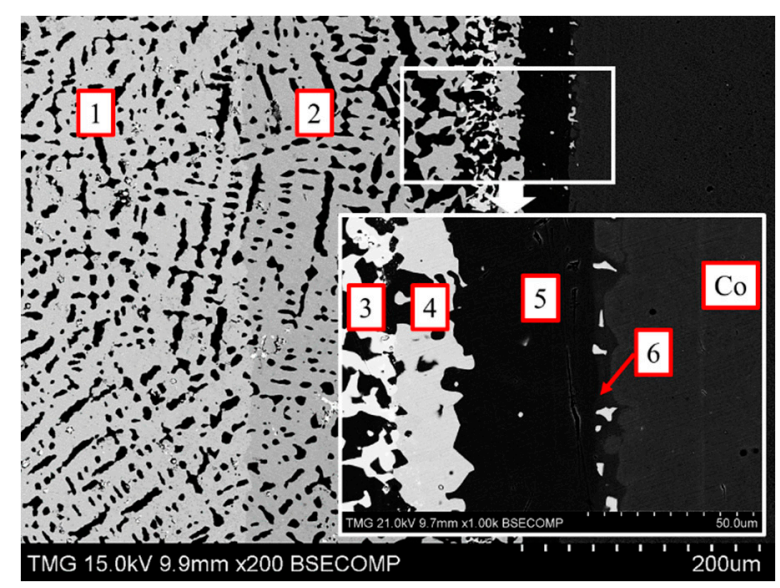

(a)

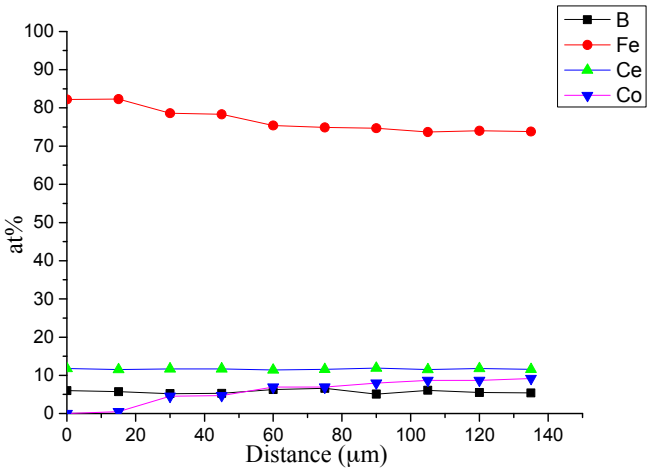

(b)

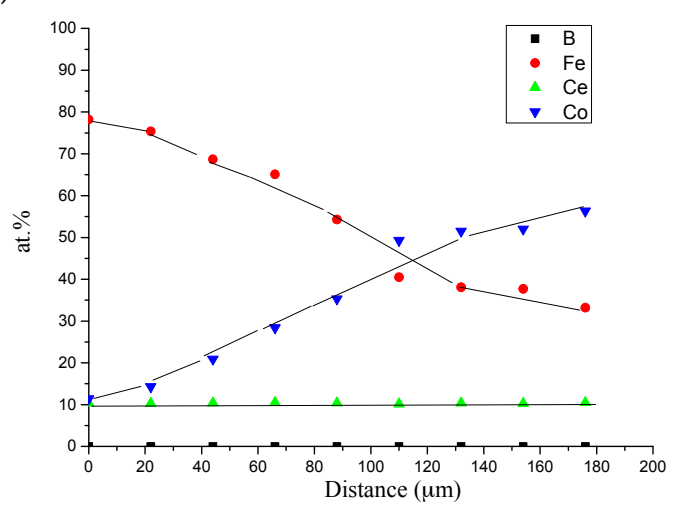

(c)

Figure 5. (a) BSE image of DC1; (b) WDS compositional profile of $\mathrm{Ce}_{2}(\mathrm{Fe}, \mathrm{Co})_{14} \mathrm{~B}$ in layer 1 ; (c) WDS compositional profile of $\mathrm{Ce}_{2}(\mathrm{Fe}, \mathrm{Co})_{17}$ in layer 2.

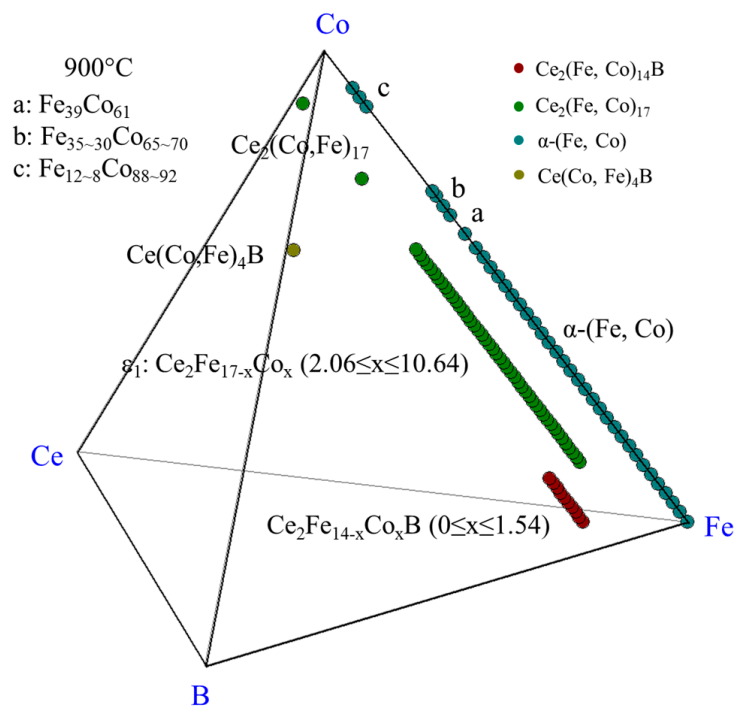

(a)

Figure 6. Cont. 


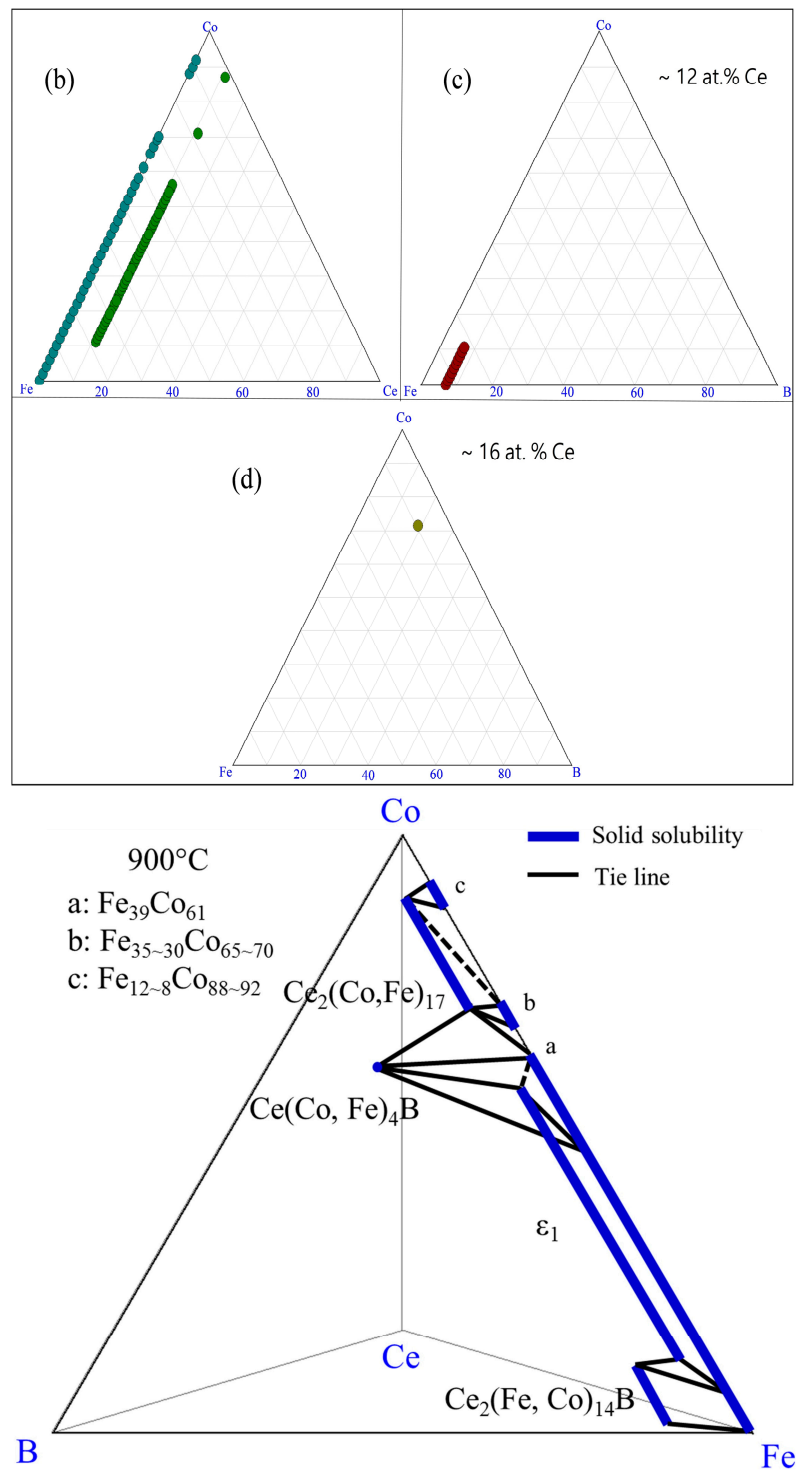

(e)

Figure 6. The results of the diffusion couple 1 at $900{ }^{\circ} \mathrm{C}$ : (a) 3D presentation of the experimental results; (b) Fe-Ce-Co ternary system; (c) pseudo ternary section at 12 at. \% Ce; (d) pseudo ternary section at $\sim 16$ at. $\% \mathrm{Ce}$; (e) phase relations obtained from DC1.

$\mathrm{Ce}_{13} \mathrm{Fe}_{80} \mathrm{~B}_{7}$ and $\mathrm{Co}_{90} \mathrm{Ce}_{10}$ were selected as the end-members of DC2. By doing so, the diffusion path may cross several phase regions, and $\mathrm{Fe} / \mathrm{Co}$ atomic exchange in $\mathrm{Ce}_{2}(\mathrm{Fe}, \mathrm{Co})_{14} \mathrm{~B}$ can be further understood. The $\mathrm{Ce}_{2}(\mathrm{Fe}, \mathrm{Co})_{14} \mathrm{~B}$ phase was confirmed in DC2 and solid solubility was measured as 22 at. \% Co which was greater than DC1. Two layers of $\mathrm{Ce}(\mathrm{Co}, \mathrm{Fe})_{4} \mathrm{~B}$ were observed in DC2, with solid solubility of 17-27 at. \% Fe and 1-6 at. \% Fe. From SEM/WDS analysis, as listed in Table 1, a single $\alpha$ - $(\mathrm{Fe}, \mathrm{Co})$ layer (layer 3$)$ formed in between of two $\mathrm{Ce}(\mathrm{Co}, \mathrm{Fe})_{4} \mathrm{~B}$ layers (layers 2 and 4$)$ which could hinder the $\mathrm{Co} / \mathrm{Fe}$ atomic exchange in $\mathrm{Ce}(\mathrm{Co}, \mathrm{Fe})_{4} \mathrm{~B}$. This is why two layers of this solid solution were obtained instead of a continuous $\mathrm{Ce}(\mathrm{Co}, \mathrm{Fe})_{4} \mathrm{~B}$ layer. $\mathrm{Ce}_{2}(\mathrm{Co}, \mathrm{Fe})_{17}$ and $\gamma-(\mathrm{Fe}, \mathrm{Co})$ two-phase equilibrium was observed and confirmed in layer 5 of DC2, as presented in Table 1. By analyzing DC3, $\mathrm{Ce}_{3}(\mathrm{Co}, \mathrm{Fe})_{11} \mathrm{~B}_{4}$ and $\mathrm{Ce}(\mathrm{Co}, \mathrm{Fe})_{12} \mathrm{~B}_{6}$ were found to form in this quaternary system at $900{ }^{\circ} \mathrm{C}$ and their solid solubilities were measured as $5-21$ at. \% Fe and 11 at. \% Fe, respectively, as can be seen in Table 1 . Later, these two phases were all confirmed by DC4. 
DC4 was designed by combining relatively high Co content $\mathrm{Ce}_{15} \mathrm{Fe}_{43} \mathrm{Co}_{19} \mathrm{~B}_{23}$ alloy with a pure $\mathrm{Co}$ piece. It is impossible to control the diffusion path of diffusion couples. Therefore, it is very essential to select the proper end-members of diffusion couples in order to cross a large number of phase regions, so that more phase equilibria results could be revealed. The BSE image of DC4 is presented in Figure 7a, the $\mathrm{Ce}_{15} \mathrm{Fe}_{43} \mathrm{Co}_{19} \mathrm{~B}_{23}$ end-member was found to be in the $\mathrm{Ce}_{13} \mathrm{Fe}_{32} \mathrm{Co}_{10} \mathrm{~B}_{45} / \mathrm{Ce}(\mathrm{Co}, \mathrm{Fe})_{4} \mathrm{~B} / \alpha-(\mathrm{Fe}, \mathrm{Co})$ three-phase region. The homogeneity range of $\mathrm{Ce}(\mathrm{Co}, \mathrm{Fe})_{4} \mathrm{~B}$ was determined as $40-45$ at. $\% \mathrm{Fe}$. A new boron-rich compound, $\mathrm{Ce}_{13} \mathrm{Fe}_{32} \mathrm{Co}_{10} \mathrm{~B}_{45}$, was found and more studies have been performed by key alloys to further analyze this compound which will be discussed in the next section. As shown in the enlarged inset of Figure 7a, four diffusion layers are present. From WDS analysis, the composition of the white phase in layer 2 was measured as $\mathrm{Ce}_{17} \mathrm{Fe}_{23-9} \mathrm{Co}_{37-51} \mathrm{~B}_{23}$, as presented in the WDS compositional profile in Figure $7 \mathrm{~b}$. Similar to DC3, this phase was identified as $\mathrm{Ce}_{3}(\mathrm{Co}, \mathrm{Fe})_{11} \mathrm{~B}_{4}$, which was also confirmed by key alloys. Layer 3 mainly contained a $\mathrm{Ce}(\mathrm{Co}, \mathrm{Fe}){ }_{12} \mathrm{~B}_{6}$ phase which had $\mathrm{Ce}_{6} \mathrm{Fe}_{18-9} \mathrm{Co}_{46-55} \mathrm{~B}_{30}$ composition. The results of WDS compositional analysis of layer 3 are plotted in Figure 7c. From DC3 and DC4, a $\mathrm{Ce}(\mathrm{Co}, \mathrm{Fe})_{12} \mathrm{~B}_{6}$ phase is confirmed. Key alloys are used to measure its maximum solubility at $900{ }^{\circ} \mathrm{C}$. A thick layer number 4 , which contained $\alpha$-(Fe, Co) with $\mathrm{Fe}_{31} \mathrm{Co}_{69}$ composition, formed in this diffusion couple.

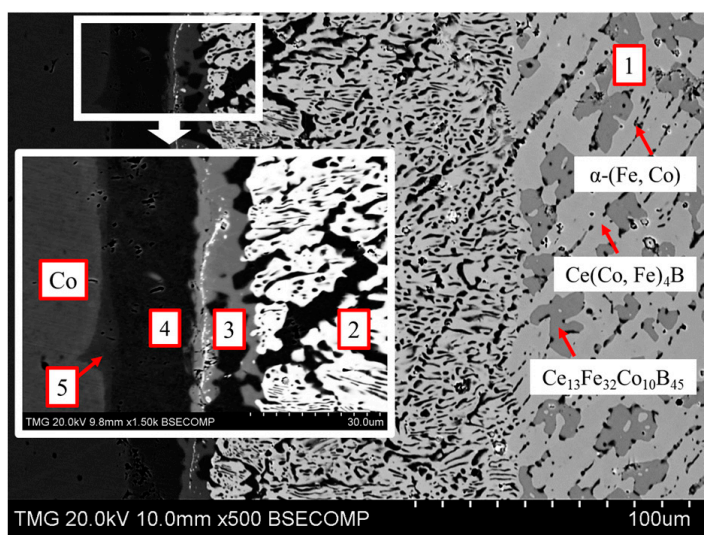

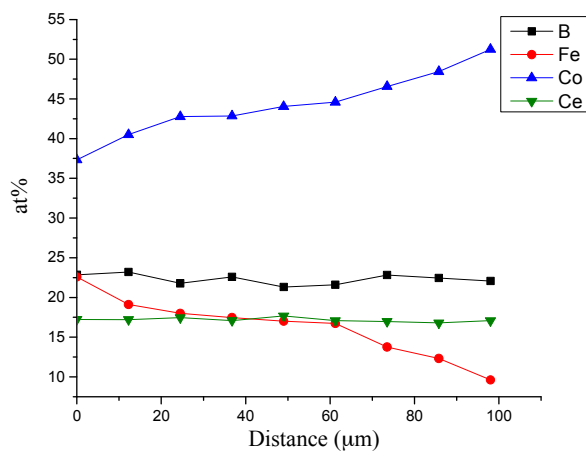

(b)

(a)

Figure 7. (a) BSE image of DC4; (b) WDS compositional profile of $\mathrm{Ce}_{3}(\mathrm{Co}, \mathrm{Fe})_{11} \mathrm{~B}_{4}$ in layer 2 ; (c) WDS compositional profile of $\mathrm{Ce}(\mathrm{Co}, \mathrm{Fe}){ }_{12} \mathrm{~B}_{6}$ in layer 3 .

The experimental results of DC4 are summarized in the 3D view shown in Figure 8a. Different phases are demonstrated by different colors. The $\alpha-(\mathrm{Fe}, \mathrm{Co})$ phase is projected on a Fe-Co-Ce ternary system in Figure 8b. The phases detected from this diffusion couple are illustrated by three pseudo ternary sections at 6 at. \%, 12 at. \%, and 16 at. \% Ce, which are shown in Figure 8c-e. The phase relations in DC4 are plotted in Figure 8f. Solid lines represent the phase regions established from DC4 and dotted lines indicate possible phase equilibria among detected phases. 


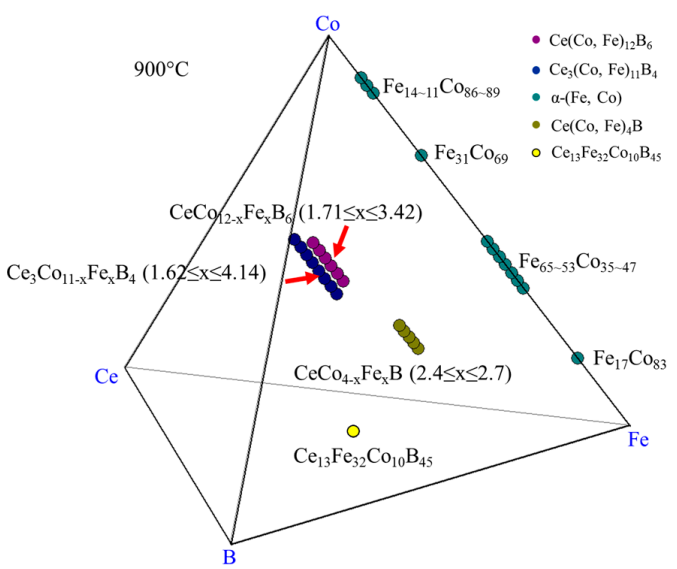

(a)

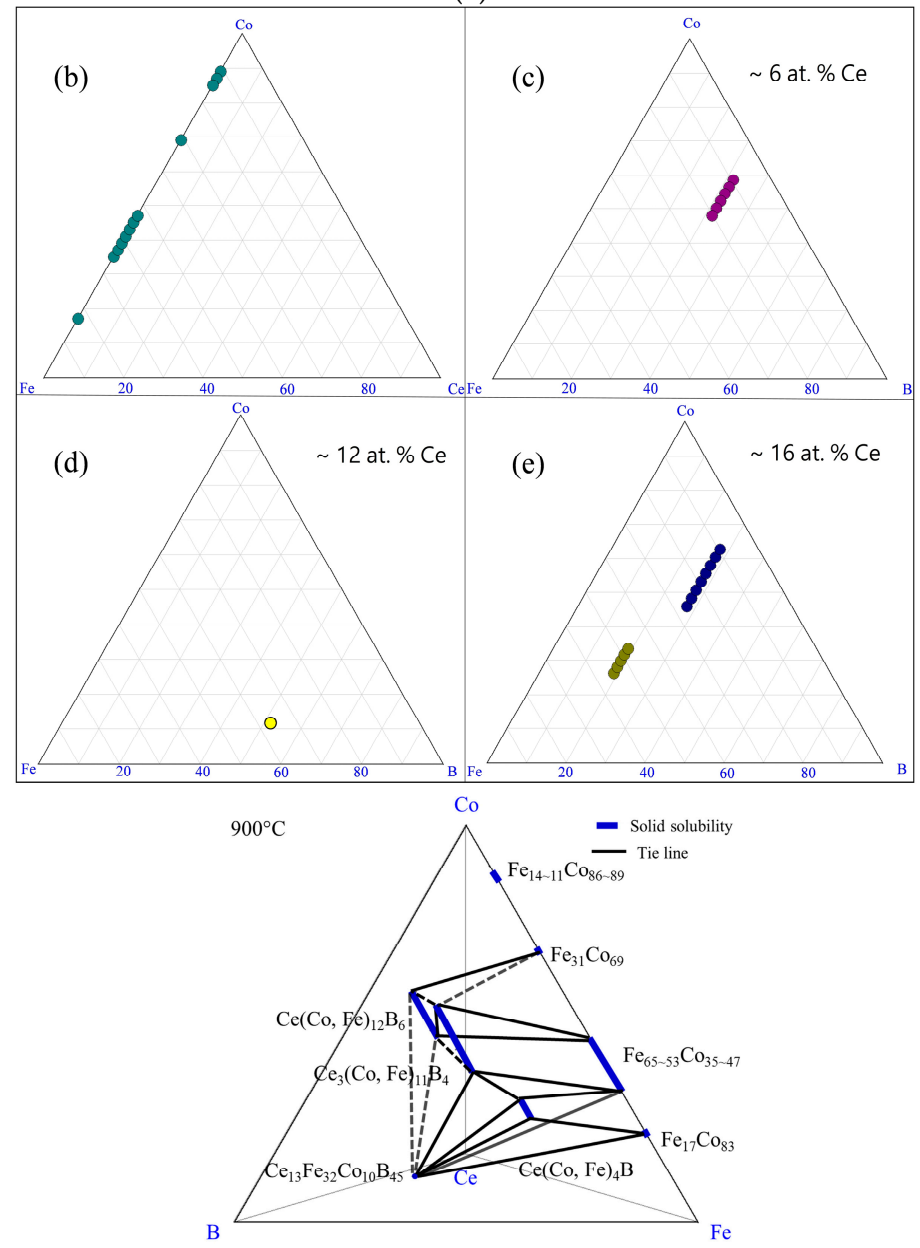

(f)

Figure 8. The results of the diffusion couple 4 at $900{ }^{\circ} \mathrm{C}$ : (a) 3D presentation of the experimental results; (b) Fe-Ce-Co ternary system; (c) pseudo ternary section at $\sim 6$ at. $\% \mathrm{Ce}$; (d) pseudo ternary section at $\sim 12$ at. \% Ce; (e) pseudo ternary section at $\sim 16$ at. \% Ce; (f) phase relations obtained from DC4.

By combining the results of all the diffusion couples, the detected phases in the Ce-Fe-Co-B system at $900{ }^{\circ} \mathrm{C}$ are plotted in Figure 9a. The phases present in the Fe-Co-Ce system are presented in Figure 9b. Three pseudo ternary sections at around 6 at. \%, 12 at. \%, and 16 at. \% Ce are also shown in Figure 9c-e, respectively. So far, $\mathrm{Ce}_{2}(\mathrm{Fe}, \mathrm{Co})_{14} \mathrm{~B}$ was found to have solid solubility of 22 at. \% Co and presented as $\mathrm{Ce}_{2} \mathrm{Fe}_{14-x} \mathrm{Co}_{x} \mathrm{~B}(0 \leq x \leq 3.78)$. Solid solubility of $\mathrm{Ce}(\mathrm{Co}, \mathrm{Fe})_{4} \mathrm{~B}$ was measured from the diffusion 
couples. Further analysis will be performed using key alloys to measure its solubility limit and will be discussed below. $\mathrm{Ce}(\mathrm{Co}, \mathrm{Fe})_{12} \mathrm{~B}_{6}$ and $\mathrm{Ce}_{3}(\mathrm{Co}, \mathrm{Fe})_{11} \mathrm{~B}_{4}$ were found to form in the $\mathrm{Ce}-\mathrm{Fe}-\mathrm{Co}-\mathrm{B}$ system at $900{ }^{\circ} \mathrm{C}$. They are denoted as $\mathrm{CeCo}_{12-x} \mathrm{Fe}_{x} \mathrm{~B}_{6}(1.7 \leq x \leq 3.42)$ and $\mathrm{Ce}_{3} \mathrm{Co}_{11-x} \mathrm{Fe}_{x} \mathrm{~B}_{4}(0.9 \leq x \leq 4.14)$, respectively. Two solid solutions, namely, $\varepsilon_{1}$ and $\varepsilon_{2}$, with the same crystal structure, were found to form between $\mathrm{Ce}_{2} \mathrm{Co}_{17}$ and $\mathrm{Ce}_{2} \mathrm{Fe}_{17}$ in the Ce-Fe-Co ternary system at $900{ }^{\circ} \mathrm{C}$, as shown in Figure $9 \mathrm{a}, \mathrm{b}$. Fujii et al. [28] studied the Ce-Fe-Co system and reported the $\mathrm{Ce}_{2} \mathrm{Co}_{13} \mathrm{Fe}_{4}$ compound. Although this compound is not observed in the current work, its composition is very close to the solubility limit of $\varepsilon_{2}$ that has the $\mathrm{Ce}_{2} \mathrm{Co}_{13.4} \mathrm{Fe}_{3.6}$ formula. Therefore, it could be that the compound reported in the work of Fujii et al. [28] refers to the solubility limit of $\varepsilon_{2}$.

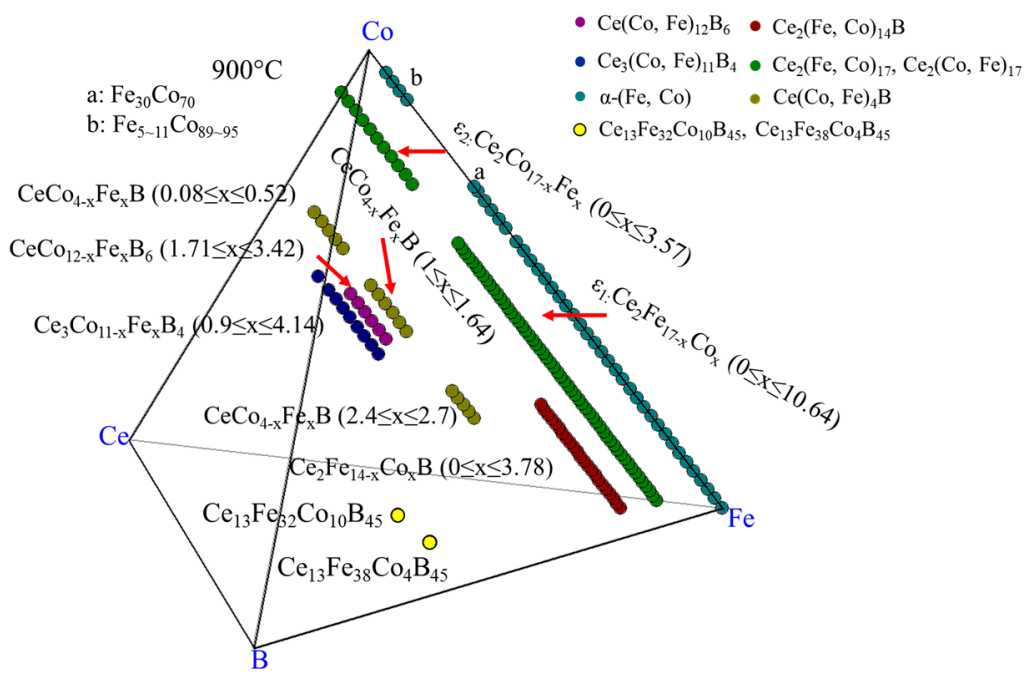

(a)

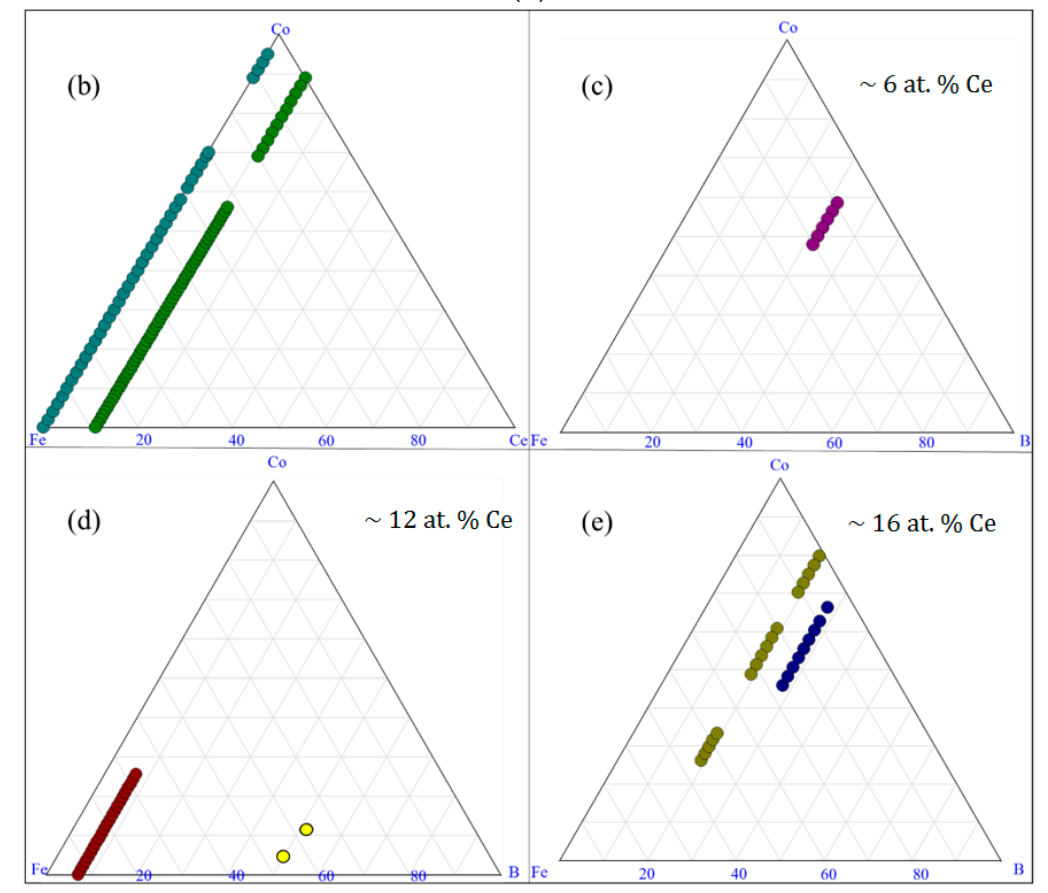

Figure 9. The diffusion couples results of the Ce-Fe-Co-B system at $900{ }^{\circ} \mathrm{C}:(\mathbf{a}) 3 \mathrm{D}$ presentation of the experimental results; (b) Fe-Ce-Co ternary system; (c) pseudo ternary section at $\sim 6$ at. $\% \mathrm{Ce}$; (d) pseudo ternary section at $\sim 12$ at. $\% \mathrm{Ce}$; (e) pseudo ternary section at $\sim 16$ at. $\%$ Ce. 


\subsection{MFM Study on Diffusion Couples}

The strength of the near-surface stray fields is sensitive to the crystal orientation [29]. Since the investigated samples are non-oriented, various types of domain patterns are present. Diffusion layers of diffusion couple 1 were investigated using MFM. A stripe domain pattern of $\mathrm{Ce}_{2} \mathrm{Fe}_{14-x} \mathrm{Co}_{x} \mathrm{~B}$ $(0 \leq x \leq 1.54)$ in layer 1 was obtained and shown in Figure 10. Three tests were performed starting from the edge of layer 1 to the interface between layers 1 and 2. As presented in Figure 10, three MFM images positively indicate that $\mathrm{Ce}_{2} \mathrm{Fe}_{14-x} \mathrm{Co}_{x} \mathrm{~B}(0 \leq x \leq 1.54)$ is magnetic along its homogeneity range. Figure 10c shows the MFM image taken at the interface of layers 1 and 2. The magnetic domain pattern of $\mathrm{Ce}_{12} \mathrm{Fe}_{73} \mathrm{Co}_{9} \mathrm{~B}_{6}\left(\mathrm{Ce}_{2} \mathrm{Fe}_{14-x} \mathrm{Co}_{x} \mathrm{~B}(x=1.54)\right)$ is shown on the left side of Figure 10c; strong magnetic contrast is detected. Comparatively, magnetic interaction of $\varepsilon_{1}$ was weak and no strong magnetic contrast can be seen on the right side of Figure 10c.

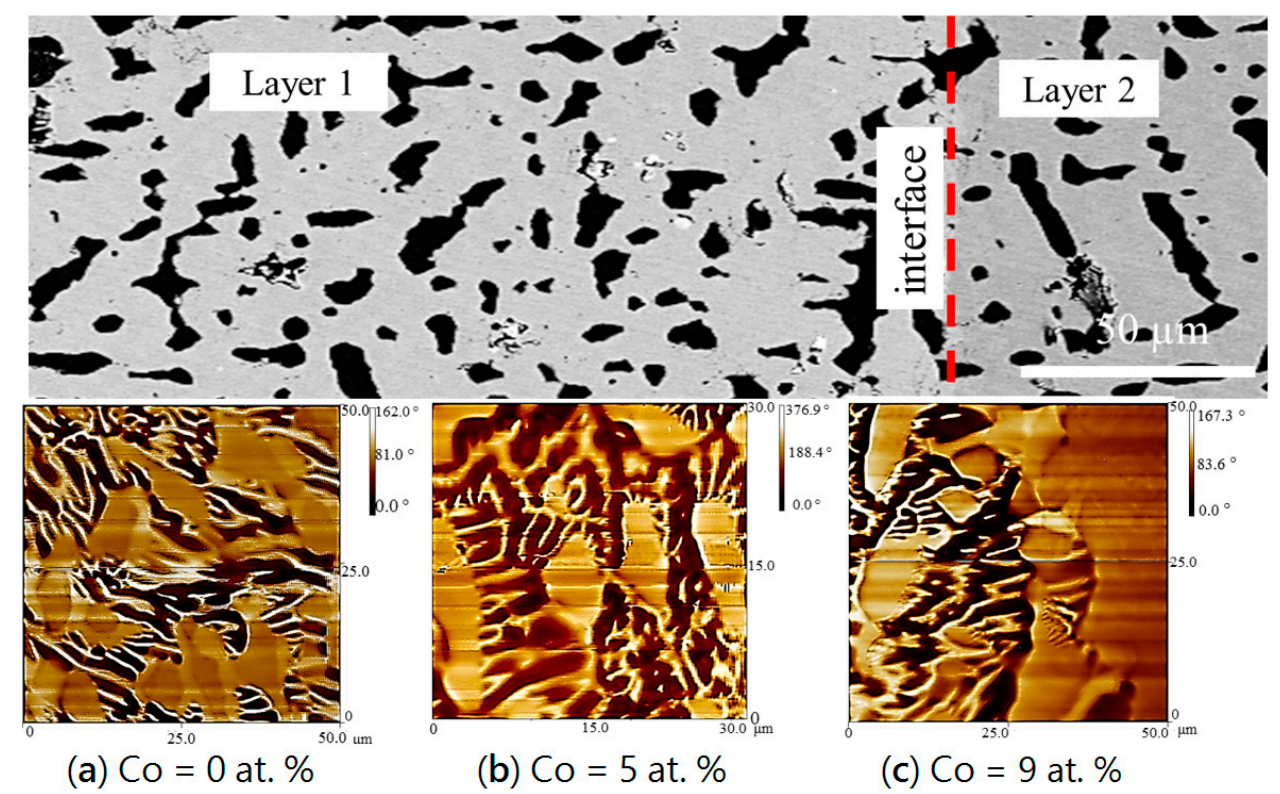

Figure 10. Microstructure (top) and three MFM images (a-c) obtained from layer 1 to the interface with layer 2 of DC1.

An MFM study was also performed on DC4. Two tests were selected to examine the regions of layers 1 and 2, and layers 2-4 as shown in Figure 11. From the MFM results illustrated in Figure 11a, magnetic contrasts of layers $2-4$ were captured. On the left side, $\alpha-(\mathrm{Fe}, \mathrm{Co})$ with the $\mathrm{Fe}_{31} \mathrm{Co}_{69}$ composition is found to be magnetic and the stripe domain pattern is clearly observed. Also, $\mathrm{Ce}(\mathrm{Co}, \mathrm{Fe})_{12} \mathrm{~B}_{6}$ in layer 3 is non-magnetic, because no magnetic contrast can be seen in the MFM analysis. Figure $11 \mathrm{~b}$ is the MFM image at the interface between the end-member $\left(\mathrm{Ce}_{15} \mathrm{Fe}_{43} \mathrm{Co}_{19} \mathrm{~B}_{23}\right)$ and layer 2; stronger magnetic contrast was observed at the end-member side $\left(\mathrm{Ce}(\mathrm{Co}, \mathrm{Fe})_{4} \mathrm{~B}\right)$, which has a mixture of stripe and closure magnetic domain patterns. Comparatively, a similar domain pattern is observed in layer $2\left(\mathrm{Ce}_{3}(\mathrm{Co}, \mathrm{Fe})_{11} \mathrm{~B}_{4}\right)$, but the magnetic interaction is weaker. The boron-rich phase, $\mathrm{Ce}_{13} \mathrm{Fe}_{32} \mathrm{Co}_{10} \mathrm{~B}_{45}$, in the end-member is non-magnetic. Complete analysis of the effect of Co solubility on the intrinsic magnetic properties of the observed phases will soon be reported elsewhere. 


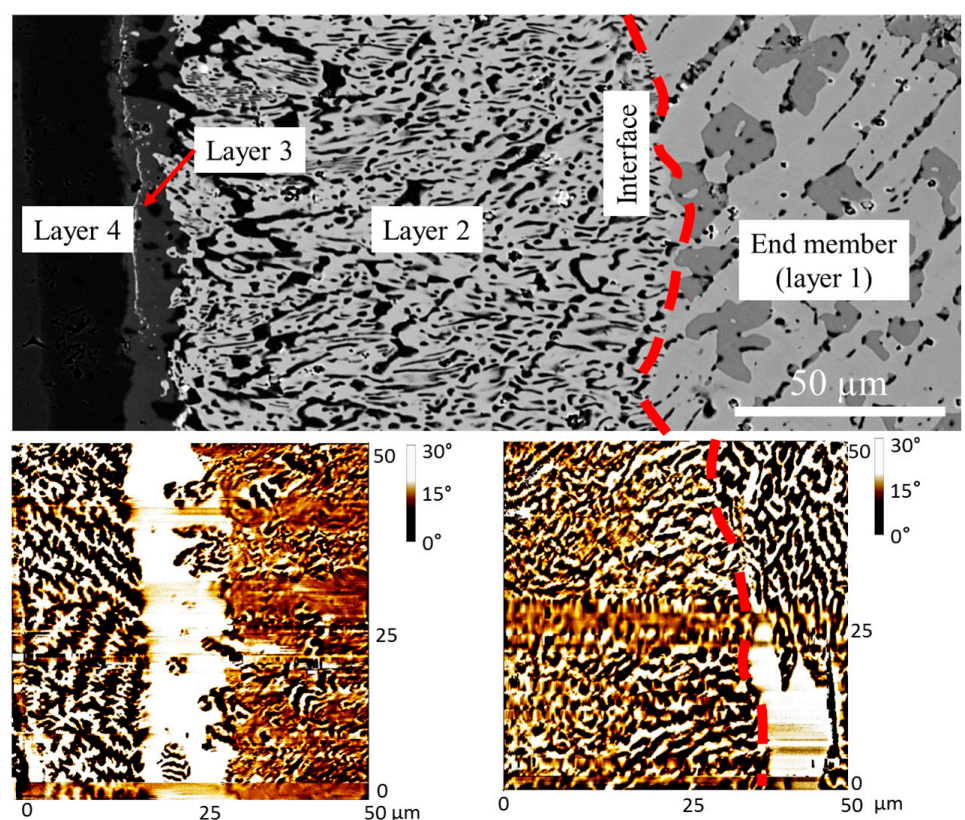

(a)

(b)

Figure 11. Microstructure (top) and two MFM images: (a) MFM test on layers 2-4 of DC4; (b) MFM test on the interface between layers 1 and 2 of DC4.

\subsection{Key Alloys Study}

\subsubsection{Homogeneity ranges of $\mathrm{Ce}_{2}(\mathrm{Fe}, \mathrm{Co})_{14} \mathrm{~B}$ and $\mathrm{Ce}(\mathrm{Co}, \mathrm{Fe})_{4} \mathrm{~B}$}

From diffusion couple studies, $\mathrm{Ce}_{2}(\mathrm{Fe}, \mathrm{Co})_{14} \mathrm{~B}$ and $\mathrm{Ce}(\mathrm{Co}, \mathrm{Fe})_{4} \mathrm{~B}$ exhibited extended homogeneity ranges in the $\mathrm{Ce}-\mathrm{Fe}-\mathrm{Co}-\mathrm{B}$ system at $900{ }^{\circ} \mathrm{C}$. Eight key alloys were prepared along the homogeneity range of $\mathrm{Ce}_{2}(\mathrm{Fe}, \mathrm{Co})_{14} \mathrm{~B}$ by substituting a different amount of $\mathrm{Fe}$ with $\mathrm{Co}$, as listed in Table 2 . The actual global compositions of the samples were determined by EDS area mapping. Three maps were taken for each sample. Also, the differences in the three scans were less than 2 at. \% for all the elements. All key alloys were annealed at $900{ }^{\circ} \mathrm{C}$ for 25 days. Phase equilibria obtained from the key alloys are also presented in Table 2.

Table 2. Chemical composition of key alloys and detected phases.

\begin{tabular}{|c|c|c|c|c|c|c|c|c|c|c|}
\hline \multirow{2}{*}{$\begin{array}{l}\text { Key Alloys } \\
\text { Number }\end{array}$} & \multicolumn{4}{|c|}{ Actual Global Composition (at. \%) } & \multicolumn{4}{|c|}{ WDS Composition (at. \%) } & \multicolumn{2}{|c|}{ Corresponding Phases } \\
\hline & $\mathrm{Ce}$ & $\mathrm{Fe}$ & Co & B & $\mathrm{Ce}$ & $\mathrm{Fe}$ & Co & B & By WDS & By XRD \\
\hline KA 1 & 14 & 73 & 7 & 6 & 12 & 76 & 6 & 6 & $\mathrm{Ce}_{2}(\mathrm{Fe}, \mathrm{Co})_{14} \mathrm{~B}$ & $\mathrm{Ce}_{2}(\mathrm{Fe}, \mathrm{Co})_{14} \mathrm{~B}$ \\
\hline \multirow{3}{*}{ KA 2} & \multirow{3}{*}{15} & \multirow{3}{*}{66} & \multirow{3}{*}{12} & \multirow{3}{*}{7} & 12 & 71 & 11 & 6 & $\mathrm{Ce}_{2}(\mathrm{Fe}, \mathrm{Co})_{14} \mathrm{~B}$ & $\mathrm{Ce}_{2}(\mathrm{Fe}, \mathrm{Co})_{14} \mathrm{~B}$ \\
\hline & & & & & 16 & 54 & 15 & 15 & $\mathrm{Ce}(\mathrm{Co}, \mathrm{Fe})_{4} \mathrm{~B}$ & $\mathrm{Ce}(\mathrm{Co}, \mathrm{Fe})_{4} \mathrm{~B}$ \\
\hline & & & & & 36 & 41 & 23 & 0 & CeFeCo & CeFeCo \\
\hline \multirow[t]{2}{*}{ KA 3} & \multirow[t]{2}{*}{14} & \multirow[t]{2}{*}{58} & \multirow[t]{2}{*}{20} & \multirow[t]{2}{*}{8} & 16 & 46 & 23 & 15 & $\mathrm{Ce}(\mathrm{Co}, \mathrm{Fe})_{4} \mathrm{~B}$ & $\mathrm{Ce}(\mathrm{Co}, \mathrm{Fe})_{4} \mathrm{~B}$ \\
\hline & & & & & 0 & 86 & 14 & 0 & $\alpha-(\mathrm{Fe}, \mathrm{Co})$ & $\alpha-(\mathrm{Fe}, \mathrm{Co})$ \\
\hline \multirow{3}{*}{ KA 4} & \multirow{3}{*}{15} & \multirow{3}{*}{54} & \multirow{3}{*}{24} & \multirow{3}{*}{7} & 12 & 60 & 22 & 6 & $\mathrm{Ce}_{2}(\mathrm{Fe}, \mathrm{Co})_{14} \mathrm{~B}$ & $\mathrm{Ce}_{2}(\mathrm{Fe}, \mathrm{Co})_{14} \mathrm{~B}$ \\
\hline & & & & & 16 & 40 & 28 & 16 & $\mathrm{Ce}(\mathrm{Co}, \mathrm{Fe})_{4} \mathrm{~B}$ & $\mathrm{Ce}(\mathrm{Co}, \mathrm{Fe})_{4} \mathrm{~B}$ \\
\hline & & & & & 0 & 80 & 20 & 0 & $\alpha-(\mathrm{Fe}, \mathrm{Co})$ & $\alpha-(\mathrm{Fe}, \mathrm{Co})$ \\
\hline KA 5 & 14 & 46 & 32 & 8 & 12 & 54 & 28 & 6 & $\mathrm{Ce}_{2}(\mathrm{Fe}, \mathrm{Co})_{14} \mathrm{~B}$ & $\mathrm{Ce}_{2}(\mathrm{Fe}, \mathrm{Co})_{14} \mathrm{~B}$ \\
\hline \multirow[t]{2}{*}{ KA 6} & \multirow[t]{2}{*}{12} & \multirow[t]{2}{*}{42} & \multirow[t]{2}{*}{40} & \multirow[t]{2}{*}{6} & 16 & 23 & 45 & 16 & $\mathrm{Ce}(\mathrm{Co}, \mathrm{Fe})_{4} \mathrm{~B}$ & $\mathrm{Ce}(\mathrm{Co}, \mathrm{Fe})_{4} \mathrm{~B}$ \\
\hline & & & & & 0 & 66 & 34 & 0 & $\alpha-(\mathrm{Fe}, \mathrm{Co})$ & $\alpha-(\mathrm{Fe}, \mathrm{Co})$ \\
\hline
\end{tabular}


Table 2. Cont

\begin{tabular}{|c|c|c|c|c|c|c|c|c|c|c|}
\hline \multirow{2}{*}{$\begin{array}{l}\text { Key Alloys } \\
\text { Number }\end{array}$} & \multicolumn{4}{|c|}{ Actual Global Composition (at. \%) } & \multicolumn{4}{|c|}{ WDS Composition (at. \%) } & \multicolumn{2}{|c|}{ Corresponding Phases } \\
\hline & $\mathrm{Ce}$ & $\mathrm{Fe}$ & Co & B & $\mathrm{Ce}$ & $\mathrm{Fe}$ & Co & B & By WDS & By XRD \\
\hline \multirow{3}{*}{ KA 7} & \multirow{3}{*}{12} & \multirow{3}{*}{32} & \multirow{3}{*}{50} & \multirow{3}{*}{6} & 11 & 37 & 52 & 0 & $\mathrm{Ce}_{2}(\mathrm{Fe}, \mathrm{Co})_{17}$ & $\mathrm{Ce}_{2}(\mathrm{Fe}, \mathrm{Co})_{17}$ \\
\hline & & & & & 17 & 13 & 54 & 16 & $\mathrm{Ce}(\mathrm{Co}, \mathrm{Fe})_{4} \mathrm{~B}$ & $\mathrm{Ce}(\mathrm{Co}, \mathrm{Fe})_{4} \mathrm{~B}$ \\
\hline & & & & & 0 & 57 & 43 & 0 & $\alpha-(\mathrm{Fe}, \mathrm{Co})$ & $\alpha-(\mathrm{Fe}, \mathrm{Co})$ \\
\hline \multirow{3}{*}{ KA 8} & \multirow{3}{*}{12} & \multirow{3}{*}{22} & \multirow{3}{*}{60} & \multirow{3}{*}{6} & 11 & 24 & 65 & 0 & $\mathrm{Ce}_{2}(\mathrm{Fe}, \mathrm{Co})_{17}$ & $\mathrm{Ce}_{2}(\mathrm{Fe}, \mathrm{Co})_{17}$ \\
\hline & & & & & 17 & 7 & 60 & 16 & $\mathrm{Ce}(\mathrm{Co}, \mathrm{Fe})_{4} \mathrm{~B}$ & $\mathrm{Ce}(\mathrm{Co}, \mathrm{Fe})_{4} \mathrm{~B}$ \\
\hline & & & & & 0 & 56 & 44 & 0 & $\alpha-(\mathrm{Fe}, \mathrm{Co})$ & $\alpha-(\mathrm{Fe}, \mathrm{Co})$ \\
\hline
\end{tabular}

* Not available: Unknown crystal structure which could not be confirmed by XRD.

Two phases formed in $\mathrm{KA} 1\left(\mathrm{Ce}_{14} \mathrm{Fe}_{73} \mathrm{Co}_{7} \mathrm{~B}_{6}\right)$ after annealing at $900{ }^{\circ} \mathrm{C}$ for 25 days, as shown in Figure 12a. The solid solubility of the dominating $\mathrm{Ce}_{2}(\mathrm{Fe}, \mathrm{Co})_{14} \mathrm{~B}$ was measured as 6 at. \% Co. A boron-rich compound $\left(\mathrm{Ce}_{13} \mathrm{Fe}_{39} \mathrm{Co}_{3} \mathrm{~B}_{45}\right)$ with similar chemical composition, which is found in the diffusion-couple study, is also observed in this key alloy. From the MFM test, as presented in Figure 12b, dominating stripe magnetic domain patterns with some dispersed non-magnetic plates were observed. Comparing the phase morphology between SEM and MFM images, it is concluded that the dominating $\mathrm{Ce}_{2}(\mathrm{Fe}, \mathrm{Co})_{14} \mathrm{~B}$ phase is magnetic, and non-magnetic regions belong to $\mathrm{Ce}_{13} \mathrm{Fe}_{39} \mathrm{Co}_{3} \mathrm{~B}_{45}$. In Figure $12 \mathrm{c}$, $\mathrm{Ce}_{2}(\mathrm{Fe}, \mathrm{Co})_{14} \mathrm{~B}$ is positively identified in the XRD pattern of KA 1 . However, the crystal structure prototype of $\mathrm{Ce}_{13} \mathrm{Fe}_{39} \mathrm{Co}_{3} \mathrm{~B}_{45}$ has not been reported, hence this compound cannot be verified by XRD analysis. A number of unlabeled peaks, marked by "?" in Figure 12c, may belong to $\mathrm{Ce}_{13} \mathrm{Fe}_{39} \mathrm{Co}_{3} \mathrm{~B}_{45}$.

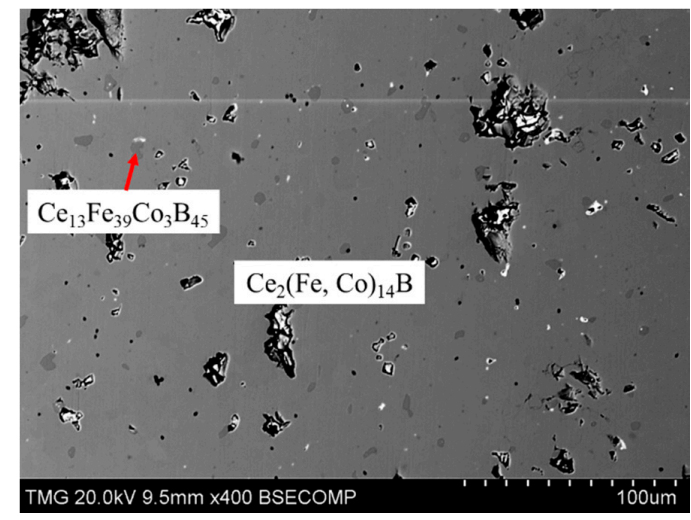

(a)

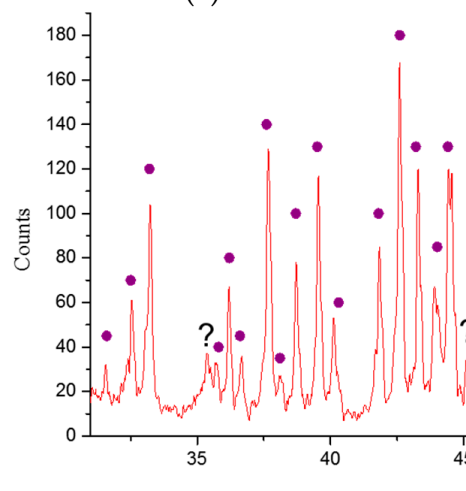

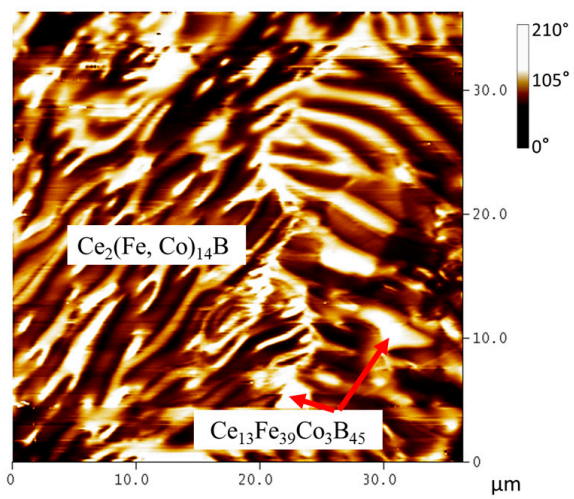

(b)

- $\mathrm{Ce} 2 \mathrm{Fe} 14 \mathrm{~B}$

? Unknown crystal structure

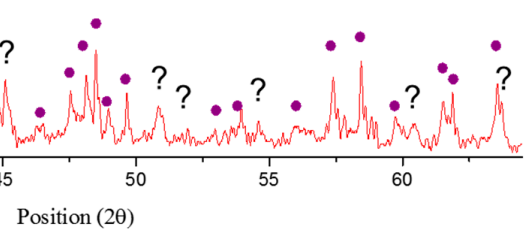

(c)

Figure 12. (a) BSE image of KA 1; (b) MFM image of KA 1; (c) XRD spectrum of KA 1.

When the concentration of $\mathrm{Co}$ in the global composition increased from 7 at. $\%$ in KA $1-12$ at. \% in KA 2, three-phase equilibrium between $\mathrm{Ce}_{2}(\mathrm{Fe}, \mathrm{Co})_{14} \mathrm{~B}, \mathrm{Ce}(\mathrm{Co}, \mathrm{Fe})_{4} \mathrm{~B}$, and $\mathrm{CeFeCo}$ occurred, as shown in Figure 13a. Unlike in KA 1, the boron-rich phase is not observed in KA 2. Instead, a limited 
quantity of $\mathrm{Ce}(\mathrm{Co}, \mathrm{Fe})_{4} \mathrm{~B}$ started to form when the Co content was increased. XRD analysis also confirmed the phase constituents, as shown in Figure $13 \mathrm{c}$. The solid solubility limit of $\mathrm{Ce}(\mathrm{Co}, \mathrm{Fe})_{4} \mathrm{~B}$ was measured as 54 at. \% Fe, which can be considered as the maximum solid solubility of this phase in the $\mathrm{Ce}-\mathrm{Fe}-\mathrm{Co}-\mathrm{B}$ system at $900{ }^{\circ} \mathrm{C}$. In the MFM image, as shown in Figure 13b, it is clear that the magnetic domain pattern corresponds to the dominating $\mathrm{Ce}_{2}(\mathrm{Fe}, \mathrm{Co}){ }_{14} \mathrm{~B}$. However, $\mathrm{Ce}(\mathrm{Co}, \mathrm{Fe}){ }_{4} \mathrm{~B}$ cannot be easily distinguished from this image, which could be due to its relatively small amount. Another possibility is that $\mathrm{Ce}(\mathrm{Co}, \mathrm{Fe})_{4} \mathrm{~B}$ and $\mathrm{Ce}_{2}(\mathrm{Fe}, \mathrm{Co})_{14} \mathrm{~B}$ have a similar magnetic domain pattern, which makes it difficult to distinguish them from each other. By comparing the morphology of CeFeCo in Figure 13a with non-magnetic islands in Figure 13b, this non-magnetic phase belongs to the CeFeCo compound.

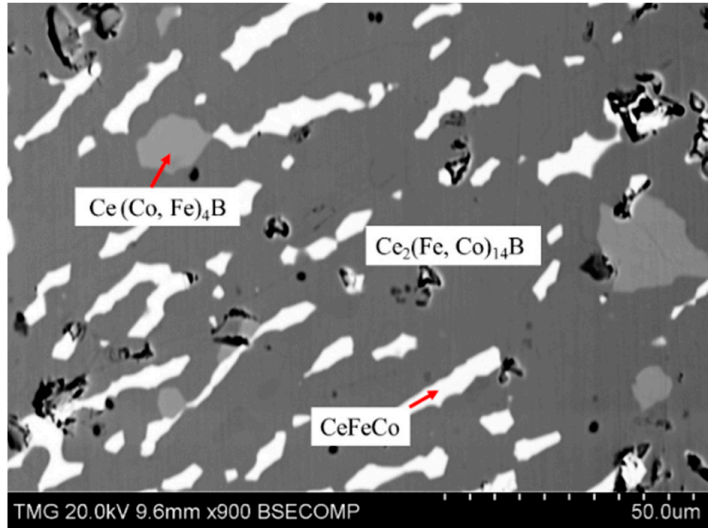

(a)

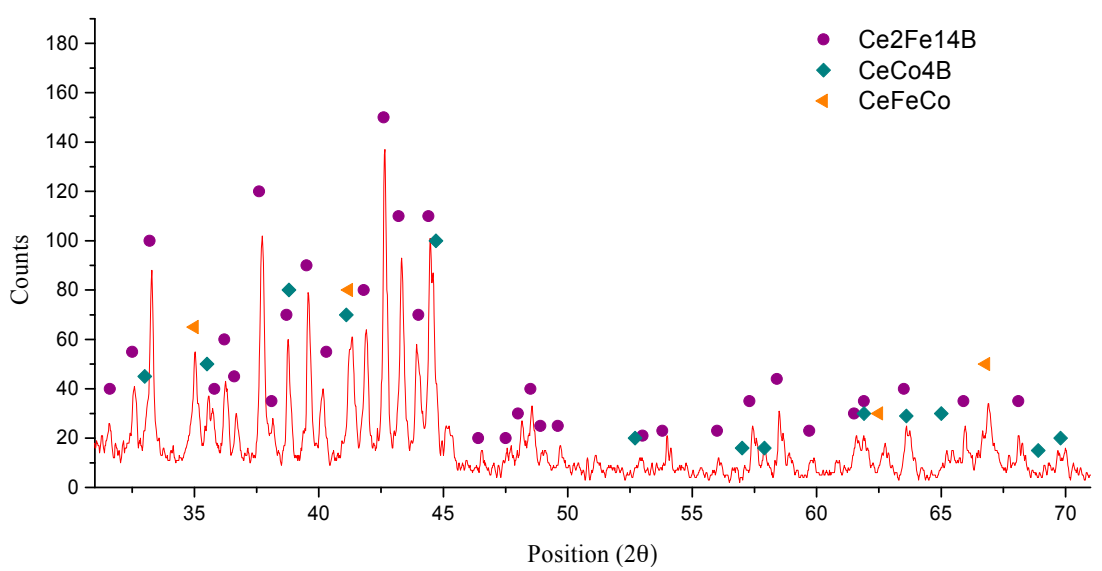

(c)

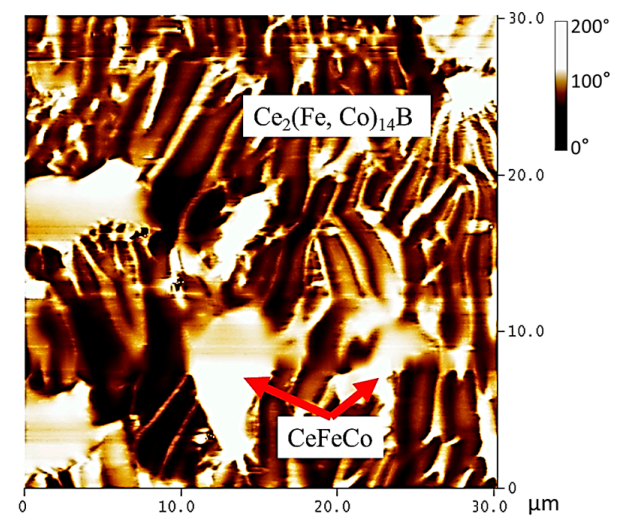

(b)
Ce2Fe14B

$\mathrm{CeCo4B}$

$\mathrm{CeFeC}$

Figure 13. (a) BSE image of KA 2; (b) MFM image of KA 2; (c) XRD spectrum of KA 2.

$\mathrm{Ce}_{2}(\mathrm{Fe}, \mathrm{Co})_{14} \mathrm{~B}$ formed through peritectic solidification. Due to the sluggish kinetics of the peritectic reaction, the transformation of $\alpha-(\mathrm{Fe}, \mathrm{Co})$ and $\mathrm{CeFeCo}$ to $\mathrm{Ce}_{2}(\mathrm{Fe}, \mathrm{Co})_{14} \mathrm{~B}$ and $\mathrm{Ce}(\mathrm{Co}, \mathrm{Fe})_{4} \mathrm{~B}$ takes a very long time. Therefore, two-phase equilibrium was established between $\mathrm{Ce}_{2}(\mathrm{Fe}, \mathrm{Co})_{14} \mathrm{~B}$ and $\mathrm{Ce}(\mathrm{Co}, \mathrm{Fe})_{4} \mathrm{~B}$ in $\mathrm{KAs} 3$, 4, and 5. In KA 3, Co dissolved in $\mathrm{Ce}_{2} \mathrm{Fe}_{14} \mathrm{~B}$ was measured as 18 at. \%. With global Co concentrations increased in KAs 4 and 5, the solid solubility of $\mathrm{Co}$ in $\mathrm{Ce}_{2} \mathrm{Fe}_{14} \mathrm{~B}$ was also further extended. Dominating $\mathrm{Ce}_{2}(\mathrm{Fe}, \mathrm{Co})_{14} \mathrm{~B}$ was found in $\mathrm{KA} 4\left(\mathrm{Ce}_{15} \mathrm{Fe}_{54} \mathrm{Co}_{24} \mathrm{~B}_{7}\right)$, as shown in Figure 14a. Solid solubility of $\mathrm{Ce}_{2}(\mathrm{Fe}, \mathrm{Co}){ }_{14} \mathrm{~B}$ was measured as 22 at. \% $\mathrm{Co}$, which is consistent with the results obtained from DC2. However, with an increase in Co content to 32 at. \% in KA 5 $\left(\mathrm{Ce}_{14} \mathrm{Fe}_{46} \mathrm{Co}_{32} \mathrm{~B}_{8}\right), \mathrm{Ce}_{2}(\mathrm{Fe}, \mathrm{Co})_{14} \mathrm{~B}$ was still found to form in this alloy, and solid solubility was measured as 28 at. \% Co. The BSE image of KA 5 is presented in Figure 14b. Magnetic domains of $\mathrm{Ce}_{2}(\mathrm{Fe}, \mathrm{Co})_{14} \mathrm{~B}$ can still be observed in both samples based on the MFM study, as can be seen in Figure 14c. KAs 6, 7 , and 8 were prepared in the Co-rich region. The compositions of the detected phases are listed 
in Table 2. When Co content in $\mathrm{KA} 6\left(\mathrm{Ce}_{12} \mathrm{Fe}_{42} \mathrm{Co}_{40} \mathrm{~B}_{6}\right)$ reached 40 at. $\%$, the $\mathrm{Ce}_{2}(\mathrm{Fe}, \mathrm{Co})_{14} \mathrm{~B}$ phase disappeared. Whereas, $\mathrm{Ce}(\mathrm{Co}, \mathrm{Fe})_{4} \mathrm{~B}$ became the dominating phase and $\mathrm{Ce}_{2}(\mathrm{Co}, \mathrm{Fe})_{17}$ started to form in KA 6. KAs 7 and 8 confirmed the phase equilibria obtained from KA 6 . In the XRD spectrum of KA 6 in Figure $15 c$, all three phases were confirmed by XRD. Three-phase regions $\mathrm{Ce}(\mathrm{Co}, \mathrm{Fe})_{4} \mathrm{~B}, \alpha-(\mathrm{Fe}, \mathrm{Co})$, and $\mathrm{Ce}_{2}(\mathrm{Co}, \mathrm{Fe})_{17}$ were established from these samples, as presented in Figure 16e. Moreover, the dominating $\mathrm{Ce}(\mathrm{Co}, \mathrm{Fe})_{4} \mathrm{~B}$ was found to be magnetic, as shown in Figure $15 \mathrm{~b}$. Compared to the MFM images of the $\mathrm{Ce}_{2}(\mathrm{Fe}, \mathrm{Co})_{14} \mathrm{~B}$ phase in $\mathrm{KAs} 1-5$, the magnetic contrast of $\mathrm{Ce}(\mathrm{Co}, \mathrm{Fe})_{4} \mathrm{~B}$ is significantly lower. The magnetic contrast of $\mathrm{Ce}(\mathrm{Co}, \mathrm{Fe})_{4} \mathrm{~B}$ in Figure $15 \mathrm{~b}$ is in the range of $0-40$ degree; whereas, the magnetic contrast of $\mathrm{Ce}_{2}(\mathrm{Fe}, \mathrm{Co})_{14} \mathrm{~B}$ in $\mathrm{KAs} 1-5$ is in the range of $0-180$ degrees or higher. This indicates that the magnetization of $\mathrm{Ce}(\mathrm{Co}, \mathrm{Fe})_{4} \mathrm{~B}$ is weaker than that of $\mathrm{Ce}_{2}(\mathrm{Fe}, \mathrm{Co})_{14} \mathrm{~B}$. In $\mathrm{KA} 6$, there is a number of weaker closure domain patterns at the top and middle of Figure 15b, which belong to $\mathrm{Ce}_{2}(\mathrm{Co}, \mathrm{Fe})_{17}$. The non-magnetic regions were considered as $\alpha-(\mathrm{Fe}, \mathrm{Co})$ which were consistent with the MFM studies of other key alloys. The MFM results are only considered as indications of the effect of composition on the magnetic domains. A detailed study of the intrinsic magnetic properties of these phases will soon be published elsewhere.

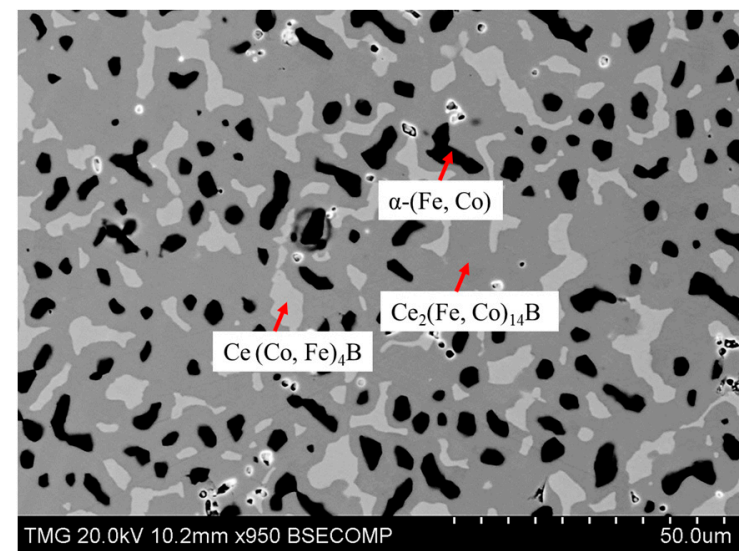

(a)

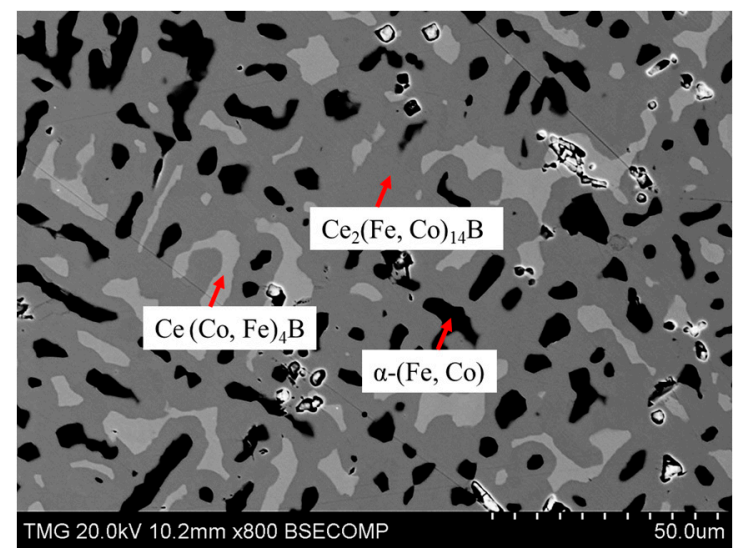

(b)

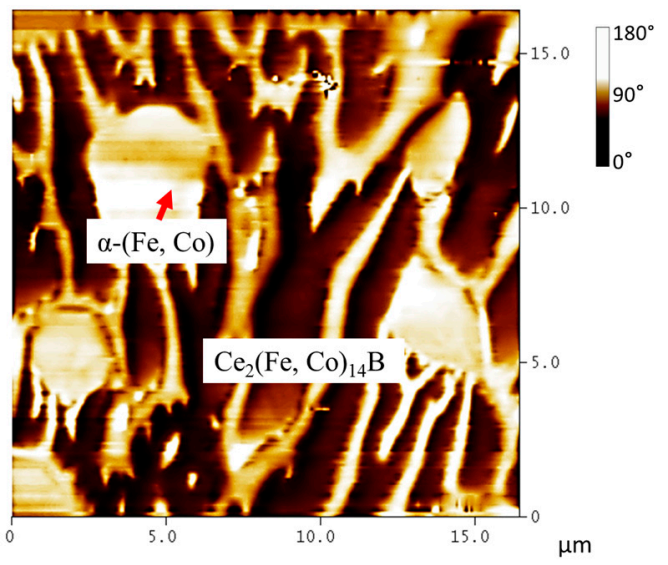

(c)

Figure 14. (a) BSE image of KA 4; (b) BSE image of KA 5; (c) MFM image of KA 5. 


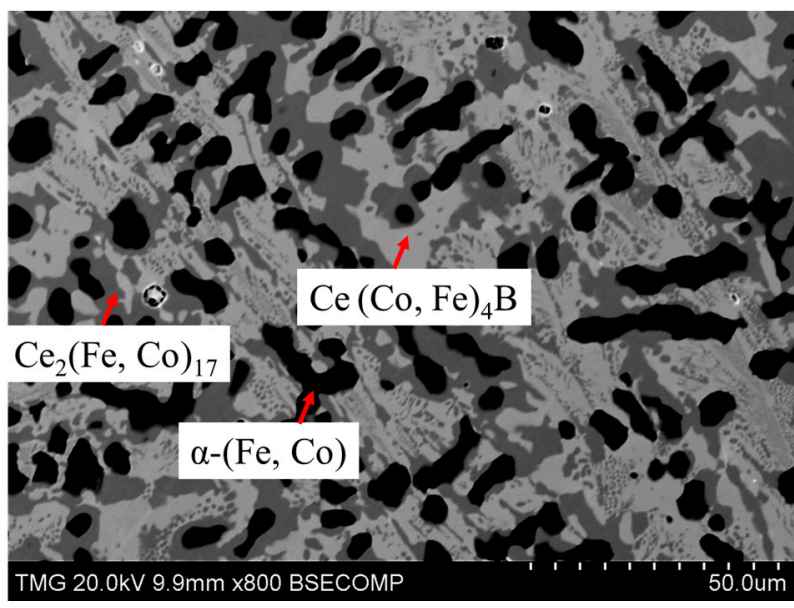

(a)

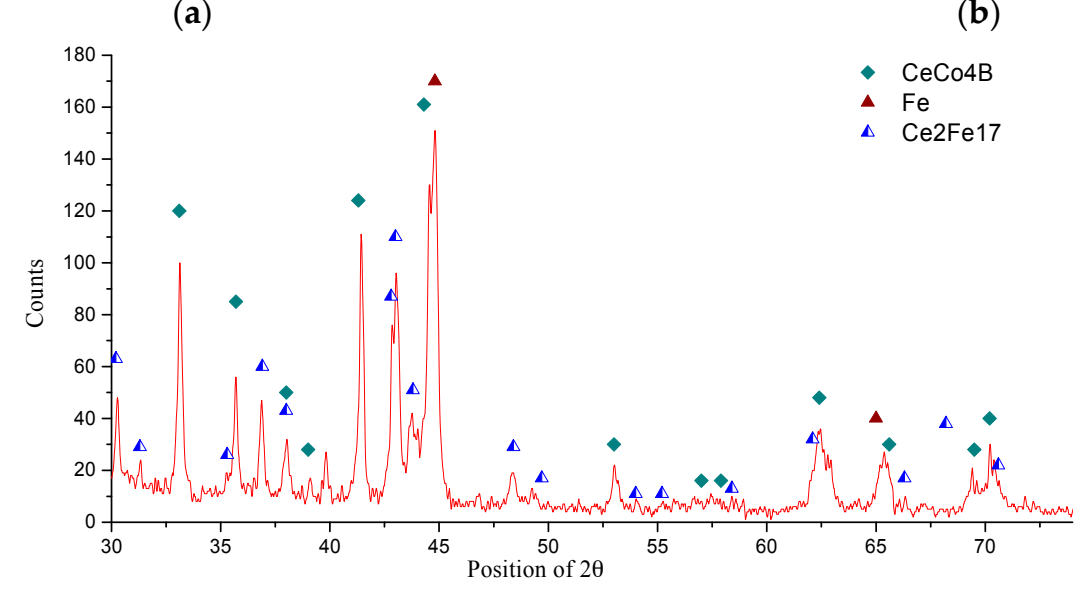

(c)

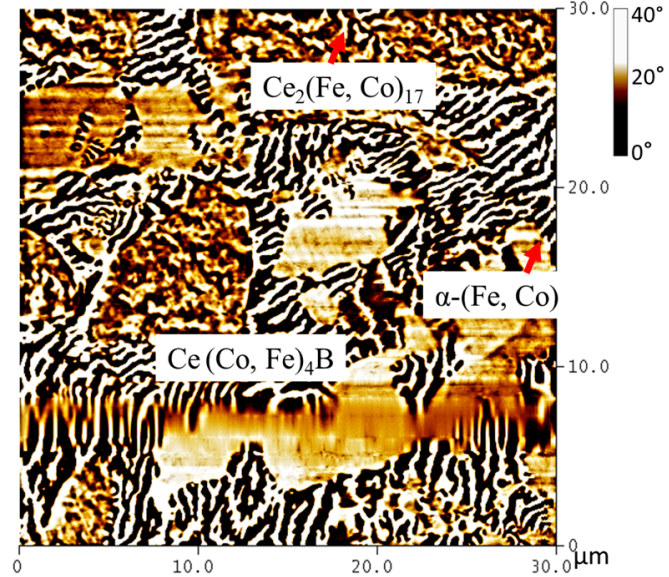

(b)

Figure 15. (a) BSE image of KA 6; (b) MFM image of KA 6; (c) XRD spectrum of KA 6.

From the key alloys study, the homogeneity ranges of $\mathrm{Ce}_{2}(\mathrm{Fe}, \mathrm{Co})_{14} \mathrm{~B}$ and $\mathrm{Ce}(\mathrm{Co}, \mathrm{Fe})_{4} \mathrm{~B}$ were measured as 28 at. $\% \mathrm{Co}$ and 54 at. \% Fe, respectively. They were presented by $\mathrm{Ce}_{2} \mathrm{Fe}_{14-x} \mathrm{Co}_{x} \mathrm{~B}$ $(1.02 \leq x \leq 4.76)$ and $\mathrm{CeCo}_{4-x} \mathrm{Fe}_{x} \mathrm{~B}(0.42 \leq x \leq 3.18)$ formulae. The experimental results of eight key alloys are summarized in Figure 16a. Solid solubility of $\varepsilon_{1}\left(\mathrm{Ce}_{2}(\mathrm{Fe}, \mathrm{Co})_{17}\right)$ observed in the diffusion couples was confirmed by key alloys 6,7 , and 8 . The Co dissolved in $\varepsilon_{1}$ was found to extend further, up to 65 at. $\%$ in $\mathrm{Ce}_{2}(\mathrm{Fe}, \mathrm{Co})_{17}$, as presented by the $\mathrm{Ce}_{2} \mathrm{Fe}_{17-x} \mathrm{Co}_{x}(7.79 \leq x \leq 12.35)$ formula and shown in Figure 16. In the current study, it is found that $\mathrm{Ce}(\mathrm{Co}, \mathrm{Fe})_{4} \mathrm{~B}$ only formed in an Fe-rich region when Co content is greater than 10 at. \%. When Co content is below 10 at. \%, the boron-rich phase, $\mathrm{Ce}_{13} \mathrm{Fe}_{39} \mathrm{Co}_{3} \mathrm{~B}_{45}$, started to form. Moreover, $\mathrm{Ce}(\mathrm{Co}, \mathrm{Fe})_{4} \mathrm{~B}$ might be a weaker magnetic phase compared to $\mathrm{Ce}_{2}(\mathrm{Fe}, \mathrm{Co})_{14} \mathrm{~B}$, based on the MFM results. The phases formed in the $\mathrm{Fe}-\mathrm{Co}-\mathrm{Ce}$ system are presented in Figure 16b. Two pseudo ternary sections at 12 at. \% and 16 at. \% Ce were used to demonstrate the locations of $\mathrm{Ce}_{2}(\mathrm{Fe}, \mathrm{Co})_{14} \mathrm{~B}$, and $\mathrm{Ce}(\mathrm{Co}, \mathrm{Fe})_{4} \mathrm{~B}$, respectively, which can be seen in Figure $16 \mathrm{c}$, d. The phase equilibria obtained from eight key alloys are presented in Figure 16e. The dotted lines indicate the possible phase equilibria between the detected phases. Two three-phase equilibria $\left(\mathrm{Ce}_{2}(\mathrm{Fe}, \mathrm{Co})_{14} \mathrm{~B} / \mathrm{Ce}(\mathrm{Co}, \mathrm{Fe})_{4} \mathrm{~B} / \mathrm{CeFeCo}\right.$ and $\left.\mathrm{Ce}(\mathrm{Co}, \mathrm{Fe})_{4} \mathrm{~B} / \alpha-(\mathrm{Fe}, \mathrm{Co}) / \mathrm{Ce}{ }_{2}(\mathrm{Fe}, \mathrm{Co})_{17}\right)$ were established. 


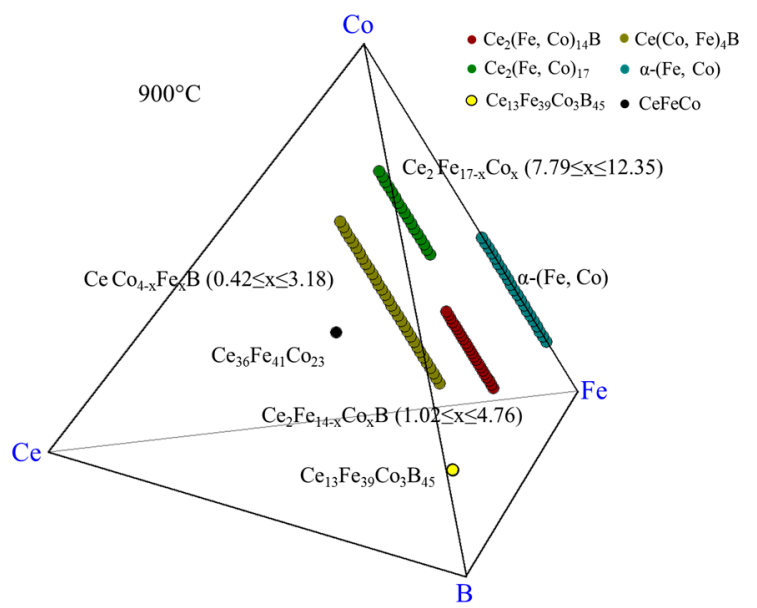

(a)
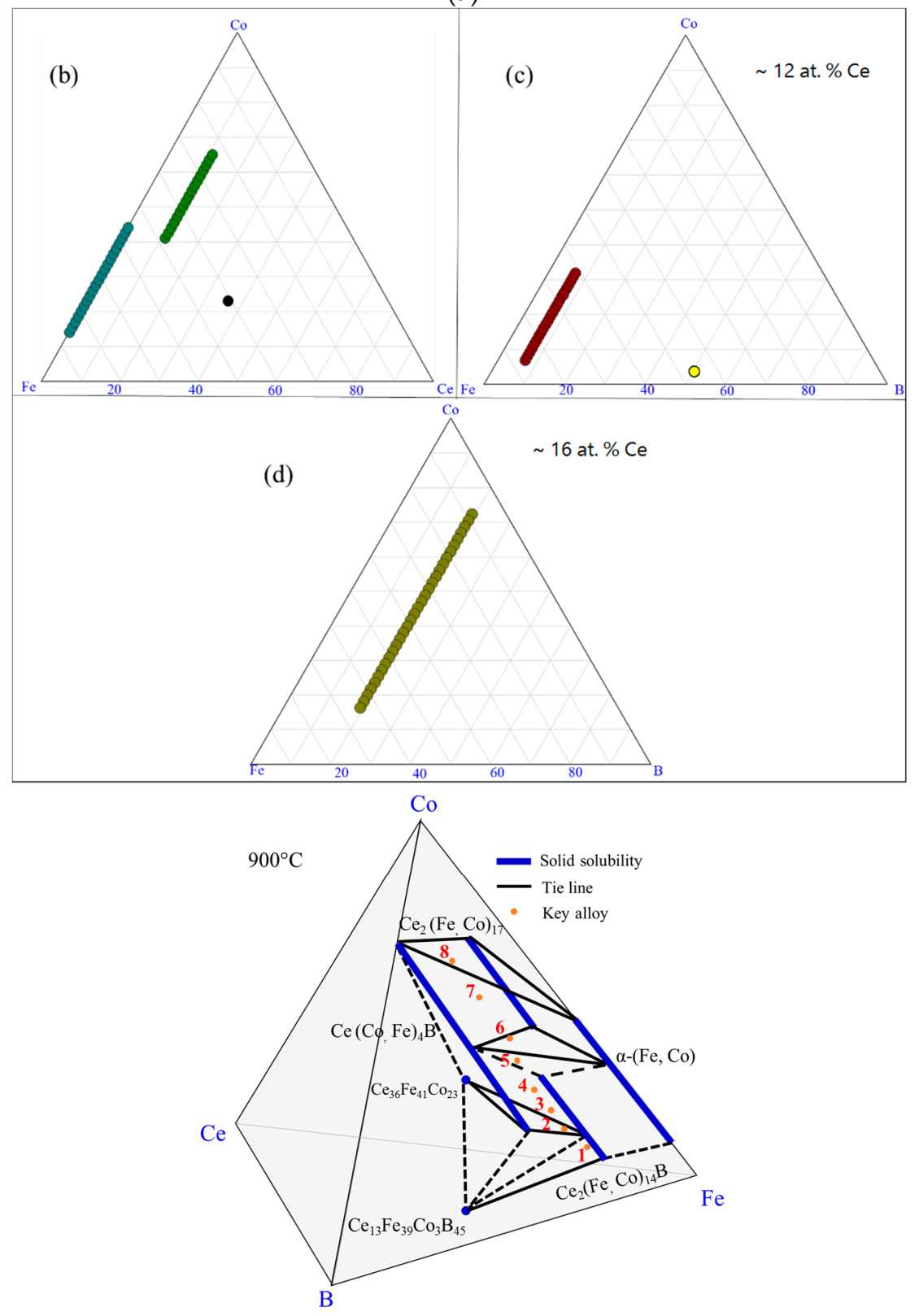

(e)

Figure 16. Homogeneity ranges of $\mathrm{Ce}_{2}(\mathrm{Fe}, \mathrm{Co}){ }_{14} \mathrm{~B}$, and $\mathrm{Ce}(\mathrm{Co}, \mathrm{Fe})_{4} \mathrm{~B}$ obtained from key alloys: (a) $3 \mathrm{D}$ presentation of the experimental results; (b) Fe-Ce-Co ternary system; (c) pseudo ternary section at $\sim 12$ at. $\%$ Ce; (d) pseudo ternary section at $\sim 16$ at. \% Ce; (e) phase relations obtained from KAs 1-8. 
$\mathrm{Ce}_{2}(\mathrm{Fe}, \mathrm{Co})_{14} \mathrm{~B}$ forms a substitutional solid solution in this quaternary system, where Co substitutes for Fe atoms, while $\mathrm{Ce}$ and $\mathrm{B}$ contents remain constant as 12 at. $\%$ and 6 at. $\%$, respectively. The maximum solid solubility of $\mathrm{Ce}_{2}(\mathrm{Fe}, \mathrm{Co})_{14} \mathrm{~B}$ has been determined by SEM/WDS as 28 at. $\% \mathrm{Co}$ in KA 5 at $900{ }^{\circ} \mathrm{C}$. All XRD data has shown that this solid solution, in KAs 1-5, crystallized in a tetragonal structure with a P42/mnm (68) space group and an $\mathrm{Nd}_{2} \mathrm{Fe}_{14} \mathrm{~B}$ prototype. Figure 17 shows the cell parameters variations with Co concentration in the selected key alloys. The peak positions shift to a higher angle with increasing Co content. The substitution of Fe with Co, which has a smaller atomic radius, decreases the unit cell parameters and lattice volumes. This is confirmed by the increase in $2 \theta$ values of the peak positions from KAs 1-5 due to the increasing Co concentration. The linear relation between the lattice parameters, lattice volume, and Co concentration obey Vegard's law [30], indicating clearly the occurrence of substitution solid solubility in the $\mathrm{Ce}_{2}(\mathrm{Fe}, \mathrm{Co}){ }_{14} \mathrm{~B}$, as plotted in Figure 17.

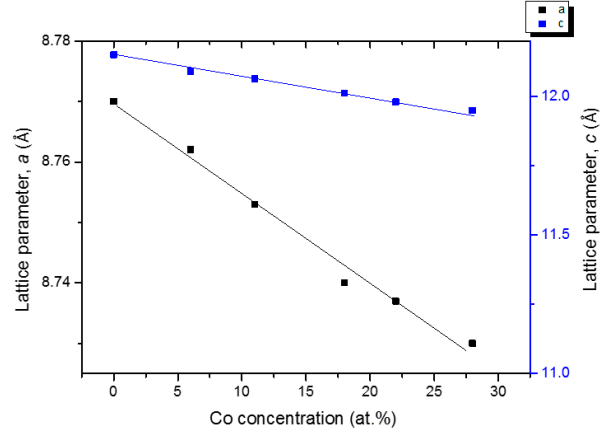

(a)

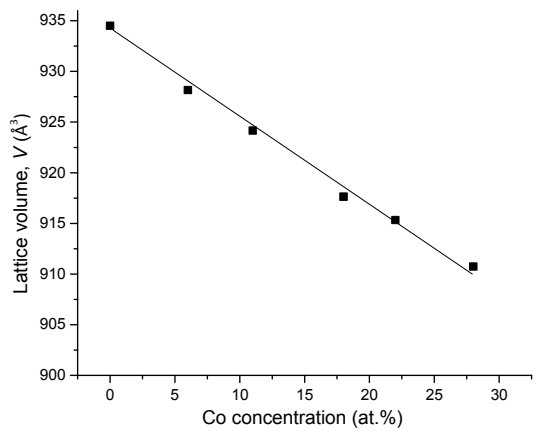

(b)

Figure 17. Cell parameters $a$ and $c$ (a) and lattice volume $V(\mathbf{b})$ with Co concentration for the $\mathrm{Ce}_{2}(\mathrm{Fe}, \mathrm{Co})_{14} \mathrm{~B}$ from KAs 1-5.

The unit cell parameters of $\mathrm{Ce}(\mathrm{Co}, \mathrm{Fe})_{4} \mathrm{~B}$ from KAs 2-6 are plotted in Figure 18. Similar to $\mathrm{Ce}_{2}(\mathrm{Fe}, \mathrm{Co})_{14} \mathrm{~B}, \mathrm{CeCo}_{4} \mathrm{~B}$ also forms a substitutional solid solution in this quaternary system, while $\mathrm{Ce}$ and $\mathrm{B}$ contents remain constant as 16 at. $\%$ and 17 at. $\%$, respectively. The substitution of Co with $\mathrm{Fe}$, which has a larger atomic radius, increases the unit cell parameters. Cell lengths $a$ and $c$ reach maximum when $\mathrm{CeCo}_{4} \mathrm{~B}$ has the maximum quaternary solid solution of 54 at. $\% \mathrm{Fe}$ in $\mathrm{KA} 2$ at $900{ }^{\circ} \mathrm{C}$. When Fe content in $\mathrm{CeCo}_{4} \mathrm{~B}$ is reduced, the cell parameters are also decreased. This is confirmed by the increase in the $2 \theta$ values of the peaks positions from the KAs $2-8$ due to the decreases in the Fe concentration. The XRD results have demonstrated that $\mathrm{Ce}(\mathrm{Co}, \mathrm{Fe})_{4} \mathrm{~B}$ crystallized in a hexagonal structure with a $\mathrm{P} 6 / \mathrm{mnm}$ (191) space group and a $\mathrm{CeCo}_{4} \mathrm{~B}$ prototype. The linear relation between the lattice parameters, lattice volume, and Co concentration obey Vegard's law [30], indicating again the occurrence of substitution solid solubility in the $\mathrm{Ce}(\mathrm{Co}, \mathrm{Fe})_{4} \mathrm{~B}$, as plotted in Figure 18.

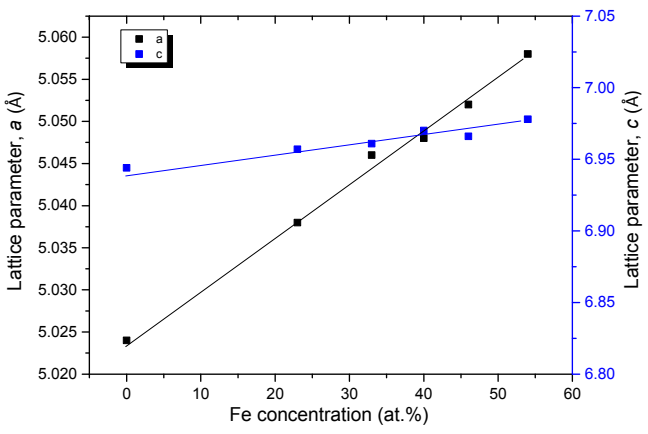

(a)

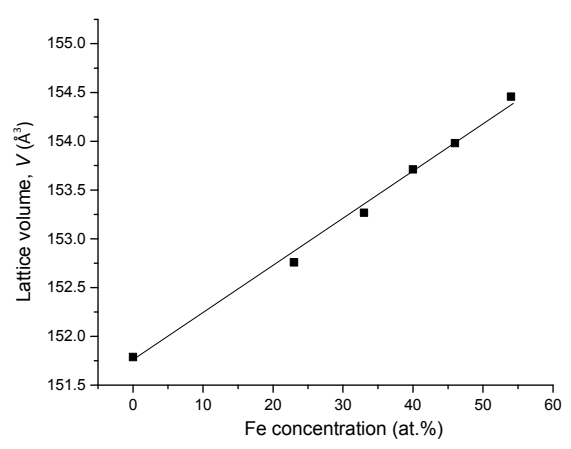

(b)

Figure 18. Cell parameters $a$ and $c$ (a) and lattice volume $V(\mathbf{b})$ with Co concentration for the $\mathrm{Ce}(\mathrm{Co}, \mathrm{Fe})_{4} \mathrm{~B}$ from KAs 2-6. 


\subsubsection{Homogeneity ranges of $\mathrm{Ce}(\mathrm{Co}, \mathrm{Fe}){ }_{12} \mathrm{~B}_{6}$ and $\mathrm{Ce}_{3}(\mathrm{Co}, \mathrm{Fe}){ }_{11} \mathrm{~B}_{4}$}

Solid solubilities of $\mathrm{Ce}(\mathrm{Co}, \mathrm{Fe})_{12} \mathrm{~B}_{6}$ and $\mathrm{Ce}_{3}(\mathrm{Co}, \mathrm{Fe})_{11} \mathrm{~B}_{4}$ were measured as 18 at. \% Fe and 23 at. \% $\mathrm{Fe}$ at $900{ }^{\circ} \mathrm{C}$ in the diffusion couple analysis. Seven key alloys were designed to verify the results obtained from the diffusion couples and determine the solubility limits of these two phases in the $\mathrm{Ce}-\mathrm{Fe}-\mathrm{Co}-\mathrm{B}$ system at $900{ }^{\circ} \mathrm{C}$. The chemical compositions of the key alloys prepared for this purpose are listed in Table 3. Phase equilibria determined from these key alloys are also summarized in Table 3. The actual global compositions of the samples were determined by EDS area mapping. Three maps were taken for each sample, and the differences in three scans were less than 2 at. $\%$ for all the elements.

Table 3. Chemical composition of key alloys and detected phases.

\begin{tabular}{|c|c|c|c|c|c|c|c|c|c|c|}
\hline \multirow{2}{*}{$\begin{array}{l}\text { Key Alloys } \\
\text { Number }\end{array}$} & \multicolumn{4}{|c|}{ Actual Global Composition (at. \%) } & \multicolumn{4}{|c|}{ WDS Composition (at. \%) } & \multicolumn{2}{|c|}{ Corresponding Phases } \\
\hline & $\mathrm{Ce}$ & $\mathrm{Fe}$ & Co & B & Ce & $\mathrm{Fe}$ & Co & B & By WDS & By XRD \\
\hline KA 9 & 9 & 7 & 56 & 28 & $\begin{array}{l}6 \\
0\end{array}$ & $\begin{array}{c}4 \\
16 \\
\end{array}$ & $\begin{array}{l}60 \\
63 \\
\end{array}$ & $\begin{array}{l}30 \\
21\end{array}$ & $\begin{array}{c}\mathrm{Ce}(\mathrm{Co}, \mathrm{Fe})_{12} \mathrm{~B}_{6} \\
\mathrm{Fe}_{16} \mathrm{Co}_{63} \mathrm{~B}_{21}\end{array}$ & $\begin{array}{c}\mathrm{Ce}(\mathrm{Co}, \mathrm{Fe})_{12} \mathrm{~B}_{6} \\
\mathrm{~N} / \mathrm{A}^{*}\end{array}$ \\
\hline KA 10 & 16 & 8 & 51 & 25 & $\begin{array}{c}17 \\
6 \\
\end{array}$ & $\begin{array}{c}5 \\
14 \\
\end{array}$ & $\begin{array}{l}55 \\
51 \\
\end{array}$ & $\begin{array}{l}23 \\
29 \\
\end{array}$ & $\begin{array}{l}\mathrm{Ce}_{3}(\mathrm{Co}, \mathrm{Fe})_{11} \mathrm{~B}_{4} \\
\mathrm{Ce}(\mathrm{Co}, \mathrm{Fe})_{12} \mathrm{~B}_{6}\end{array}$ & $\begin{array}{c}\mathrm{Ce}_{3}(\mathrm{Co}, \mathrm{Fe})_{11} \mathrm{~B}_{4} \\
\mathrm{Ce}(\mathrm{Co}, \mathrm{Fe})_{12} \mathrm{~B}_{6}\end{array}$ \\
\hline KA 11 & 17 & 18 & 43 & 22 & $\begin{array}{c}17 \\
6 \\
\end{array}$ & $\begin{array}{l}14 \\
32 \\
\end{array}$ & $\begin{array}{l}46 \\
32 \\
\end{array}$ & $\begin{array}{l}23 \\
30 \\
\end{array}$ & $\begin{array}{l}\mathrm{Ce}_{3}(\mathrm{Co}, \mathrm{Fe})_{11} \mathrm{~B}_{4} \\
\mathrm{Ce}(\mathrm{Co}, \mathrm{Fe})_{12} \mathrm{~B}_{6}\end{array}$ & $\begin{array}{l}\mathrm{Ce}_{3}(\mathrm{Co}, \mathrm{Fe})_{11} \mathrm{~B}_{4} \\
\mathrm{Ce}(\mathrm{Co}, \mathrm{Fe})_{12} \mathrm{~B}_{6}\end{array}$ \\
\hline KA 12 & 17 & 33 & 27 & 23 & $\begin{array}{c}17 \\
6 \\
17 \\
\end{array}$ & $\begin{array}{l}28 \\
46 \\
39 \\
\end{array}$ & $\begin{array}{l}32 \\
18 \\
27 \\
\end{array}$ & $\begin{array}{l}23 \\
30 \\
17 \\
\end{array}$ & $\begin{array}{c}\mathrm{Ce}_{3}(\mathrm{Co}, \mathrm{Fe})_{11} \mathrm{~B}_{4} \\
\mathrm{Ce}(\mathrm{Co}, \mathrm{Fe})_{12} \mathrm{~B}_{6} \\
\mathrm{Ce}(\mathrm{Co}, \mathrm{Fe})_{4} \mathrm{~B}\end{array}$ & $\begin{array}{c}\mathrm{Ce}_{3}(\mathrm{Co}, \mathrm{Fe})_{11} \mathrm{~B}_{4} \\
\mathrm{Ce}(\mathrm{Co}, \mathrm{Fe})_{12} \mathrm{~B}_{6} \\
\mathrm{Ce}(\mathrm{Co}, \mathrm{Fe})_{4} \mathrm{~B}\end{array}$ \\
\hline KA 13 & 17 & 42 & 18 & 23 & $\begin{array}{l}17 \\
16 \\
13 \\
\end{array}$ & $\begin{array}{l}37 \\
47 \\
34 \\
\end{array}$ & $\begin{array}{c}23 \\
20 \\
8 \\
\end{array}$ & $\begin{array}{l}23 \\
17 \\
45\end{array}$ & $\begin{array}{c}\mathrm{Ce}_{3}(\mathrm{Co}, \mathrm{Fe})_{11} \mathrm{~B}_{4} \\
\mathrm{Ce}(\mathrm{Co}, \mathrm{Fe})_{4} \mathrm{~B} \\
\mathrm{Ce}_{13} \mathrm{Fe}_{34} \mathrm{Co}_{8} \mathrm{~B}_{45} \\
\end{array}$ & $\begin{array}{c}\mathrm{Ce}_{3}(\mathrm{Co}, \mathrm{Fe})_{11} \mathrm{~B}_{4} \\
\mathrm{Ce}(\mathrm{Co}, \mathrm{Fe})_{4} \mathrm{~B} \\
\mathrm{~N} / \mathrm{A}^{*}\end{array}$ \\
\hline KA 15 & 15 & 20 & 49 & 16 & $\begin{array}{c}17 \\
16 \\
0\end{array}$ & $\begin{array}{l}16 \\
26 \\
68\end{array}$ & $\begin{array}{l}44 \\
42 \\
32\end{array}$ & $\begin{array}{c}23 \\
16 \\
0\end{array}$ & $\begin{array}{c}\mathrm{Ce}_{3}(\mathrm{Co}, \mathrm{Fe})_{11} \mathrm{~B}_{4} \\
\mathrm{Ce}(\mathrm{Co}, \mathrm{Fe})_{4} \mathrm{~B} \\
\alpha-(\mathrm{Fe}, \mathrm{Co})\end{array}$ & $\begin{array}{c}\mathrm{Ce}_{3}(\mathrm{Co}, \mathrm{Fe})_{11} \mathrm{~B}_{4} \\
\mathrm{Ce}(\mathrm{Co}, \mathrm{Fe})_{4} \mathrm{~B} \\
\alpha-(\mathrm{Fe}, \mathrm{Co})\end{array}$ \\
\hline
\end{tabular}

* Not available: Unknown crystal structure which could not be confirmed by XRD.

$\mathrm{Ce}(\mathrm{Co}, \mathrm{Fe}){ }_{12} \mathrm{~B}_{6}$ was first found in the diffusion couple study and the homogeneity range was measured as 9-18 at. \% Fe. KA 9 was prepared in the Co-rich side with $\mathrm{Ce}_{6} \mathrm{Fe}_{6} \mathrm{Co}_{58} \mathrm{~B}_{30}$ chemical composition. After annealing at $900{ }^{\circ} \mathrm{C}$ for 25 days, the dominating $\mathrm{Ce}(\mathrm{Co}, \mathrm{Fe})_{12} \mathrm{~B}_{6}$ was obtained and some precipitates with $\mathrm{Fe}_{16} \mathrm{Co}_{63} \mathrm{~B}_{21}$ chemical composition were also observed, as shown in Figure 19a. Fe dissolved in $\mathrm{CeCo}_{12} \mathrm{~B}_{6}$ was determined as 4 at. \%. From the MFM image in Figure $19 \mathrm{~b}$, the dominating phase was found to be non-magnetic, which is also consistent with the MFM result of DC4. The magnetic domain found in this image belongs to $\mathrm{Fe}_{16} \mathrm{Co}_{63} \mathrm{~B}_{21}$. Based on the XRD analysis shown in Figure $19 \mathrm{c}$, the dominating $\mathrm{Ce}(\mathrm{Co}, \mathrm{Fe}){ }_{12} \mathrm{~B}_{6}$ phase was positively identified. However, the crystal structure prototype of $\mathrm{Fe}_{16} \mathrm{Co}_{63} \mathrm{~B}_{21}$ is not available in the literature. Therefore, this phase cannot be verified by XRD analysis. Moreover, there are some unlabeled peaks, marked with "?" in Figure 19c, which may belong to $\mathrm{Fe}_{16} \mathrm{Co}_{63} \mathrm{~B}_{21}$. 


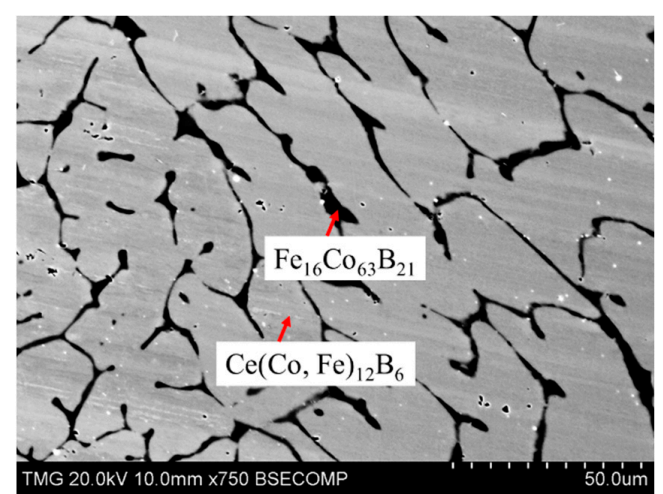

(a)

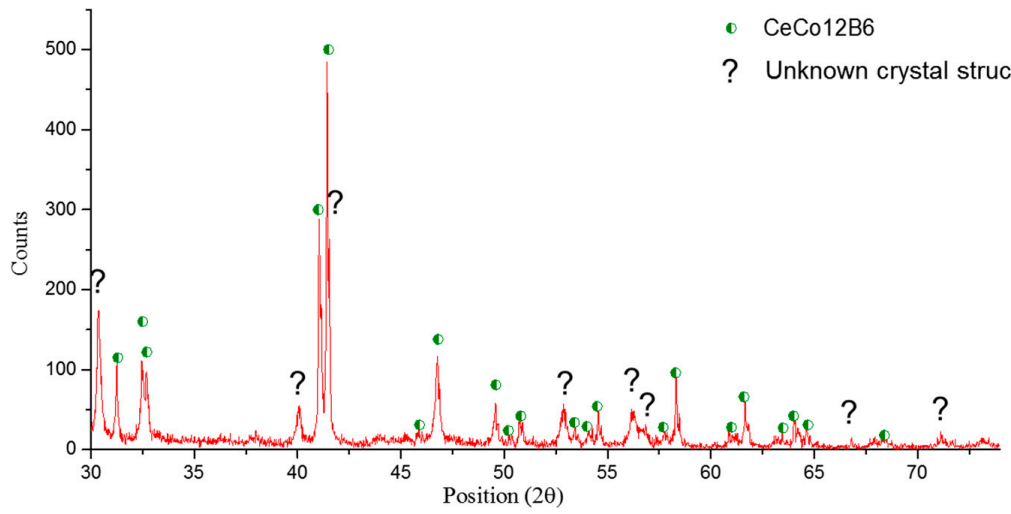

(c)

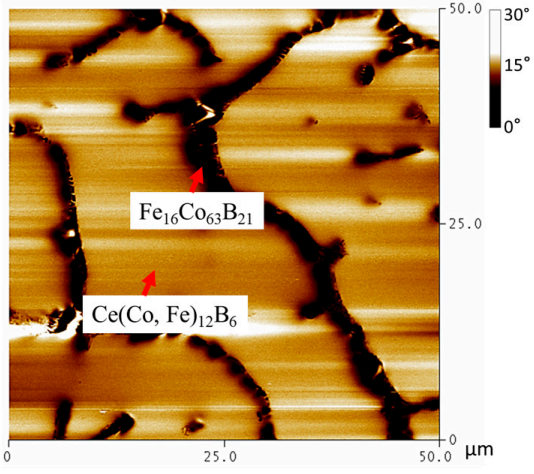

(b)

- CeCo12B

? Unknown crystal structure

Figure 19. (a) BSE image of KA 9; (b) MFM image of KA 9; (c) XRD spectrum of KA 9.

KAs 10-14 were selected to measure the maximum solid solubility of $\mathrm{Ce}(\mathrm{Co}, \mathrm{Fe}){ }_{12} \mathrm{~B}_{6}$ and $\mathrm{Ce}_{3}(\mathrm{Co}, \mathrm{Fe})_{11} \mathrm{~B}_{4}$. These five key alloys were prepared along the homogeneity range of $\mathrm{Ce}_{3}(\mathrm{Co}, \mathrm{Fe})_{11} \mathrm{~B}_{4}$ by substituting a different amount of $\mathrm{Fe}$ with $\mathrm{Co}$, which were presented by the formulae $\mathrm{Ce}_{3} \mathrm{Co}_{11-x} \mathrm{Fe}_{x} \mathrm{~B}_{4}$ with $x=1.44,3.24,5.94,7.38$, and 9.00. The phase relations between $\mathrm{Ce}_{3}(\mathrm{Co}, \mathrm{Fe})_{11} \mathrm{~B}_{4}$, $\mathrm{Ce}(\mathrm{Co}, \mathrm{Fe})_{12} \mathrm{~B}_{6}$, and $\mathrm{Ce}(\mathrm{Co}, \mathrm{Fe})_{4} \mathrm{~B}$ were investigated. As shown in Figure 20a, two-phase equilibrium between $\mathrm{Ce}_{3}(\mathrm{Co}, \mathrm{Fe})_{11} \mathrm{~B}_{4}$ and $\mathrm{Ce}(\mathrm{Co}, \mathrm{Fe})_{12} \mathrm{~B}_{6}$ was established from $\mathrm{KA}$ 11. The dominating $\mathrm{Ce}_{3}(\mathrm{Co}, \mathrm{Fe})_{11} \mathrm{~B}_{4}$ phase was identified and the black precipitates in Figure 20a were found to be $\mathrm{Ce}(\mathrm{Co}, \mathrm{Fe})_{12} \mathrm{~B}_{6}$. When the global Fe concentration in $\mathrm{KA} 12$ was increased to 33 at. \%, a small amount of the $\mathrm{Ce}(\mathrm{Co}, \mathrm{Fe})_{4} \mathrm{~B}$ phase appeared, as can be seen in Figure 20b. Fe dissolved in $\mathrm{Ce}_{3}(\mathrm{Co}, \mathrm{Fe})_{11} \mathrm{~B}_{4}$ and $\mathrm{Ce}(\mathrm{Co}, \mathrm{Fe}){ }_{12} \mathrm{~B}_{6}$ was measured as 28 at. $\%$ and 46 at. \%, respectively. The detected phases were all confirmed by XRD, as presented in Figure 20g. As Fe content reached 42 at. \% in KA 13, $\mathrm{Ce}(\mathrm{Co}, \mathrm{Fe})_{12} \mathrm{~B}_{6}$ disappeared and $\mathrm{Ce}(\mathrm{Co}, \mathrm{Fe})_{4} \mathrm{~B}$ became the dominating phase, along with a limited amount of $\mathrm{Ce}_{3}(\mathrm{Co}, \mathrm{Fe})_{11} \mathrm{~B}_{4}$.

When Fe content was increased to 50 at. \% in $\mathrm{KA} 14, \mathrm{Ce}_{3}(\mathrm{Co}, \mathrm{Fe})_{11} \mathrm{~B}_{4}$ completely disappeared and three-phase equilibrium $\mathrm{Ce}(\mathrm{Co}, \mathrm{Fe})_{4} \mathrm{~B}, \mathrm{Ce}_{13} \mathrm{Fe}_{37} \mathrm{Co}_{5} \mathrm{~B}_{45}$, and $\mathrm{CeFeCo}$ was established. Maximum solid solubility of $\mathrm{Ce}_{3}(\mathrm{Co}, \mathrm{Fe})_{11} \mathrm{~B}_{4}$ was measured as 37 at. \% Fe in KA 13. From the MFM results, as shown in Figure 20e,f, a mixture of stripe and closure domain patterns is observed, indicating that the dominating $\mathrm{Ce}_{3}(\mathrm{Co}, \mathrm{Fe})_{11} \mathrm{~B}_{4}$ dissolving 14 at. \% $\mathrm{Fe}$ and 28 at. \% $\mathrm{Fe}$, respectively, is a magnetic phase. Magnetic $\mathrm{Ce}_{3}(\mathrm{Co}, \mathrm{Fe})_{11} \mathrm{~B}_{4}$ was first found in DC4, and is now confirmed by the MFM study of the key alloys. The substitution of $\mathrm{Co}$ with $\mathrm{Fe}$ in $\mathrm{Ce}_{3}(\mathrm{Co}, \mathrm{Fe})_{11} \mathrm{~B}_{4}$ is also studied by $\mathrm{XRD}$. Compared to $\mathrm{Co}, \mathrm{Fe}$ has a larger atomic radius, which could increase the unit cell parameters. As can be seen in Figure 21, cell length $a$ and lattice volume $V$ reach maximum when $\mathrm{Ce}_{3}(\mathrm{Co}, \mathrm{Fe})_{11} \mathrm{~B}_{4}$ has the maximum quaternary solid solubility of 37 at. $\%$ Fe in KA 13 at $900{ }^{\circ} \mathrm{C}$. However, when Fe concentration in $\mathrm{Ce}_{3}(\mathrm{Co}, \mathrm{Fe})_{11} \mathrm{~B}_{4}$ was increased, the cell parameter $c$ decreased to some extent. Nevertheless, the volume of the unit cell 
increased with Fe content, indicating the overall effect of larger atom substitution. The XRD results have demonstrated that $\mathrm{Ce}_{3}(\mathrm{Co}, \mathrm{Fe})_{11} \mathrm{~B}_{4}$ crystallizes in a hexagonal structure with a P6/mnm (191) space group and a $\mathrm{Ce}_{3} \mathrm{Co}_{11} \mathrm{~B}_{4}$ prototype. The linear relation between the lattice parameters, lattice volume, and Co concentration indicates the occurrence of substitution solid solubility, according to the Vegard's law [30], as shown in Figure 21.

In KAs 13 and 14, a boron-rich phase with $\mathrm{Ce}_{13} \mathrm{Fe}_{34} \mathrm{Co}_{8} \mathrm{~B}_{45}$ and $\mathrm{Ce}_{13} \mathrm{Fe}_{37} \mathrm{Co}_{5} \mathrm{~B}_{45}$ chemical compositions was identified. This phase was first observed in DCs 3 and 4, with $\mathrm{Ce}_{13} \mathrm{Fe}_{38} \mathrm{Co}_{4} \mathrm{~B}_{45}$ and $\mathrm{Ce}_{13} \mathrm{Fe}_{32} \mathrm{Co}_{10} \mathrm{~B}_{45}$, respectively. Similar results were also obtained from KA 1, but with $\mathrm{Ce}_{13} \mathrm{Fe}_{39} \mathrm{Co}_{3} \mathrm{~B}_{45}$ composition. Analyzing these compositions reveals that $\mathrm{Ce}$ and $\mathrm{B}$ contents are consistent and the compositional difference was due to Fe/Co atomic exchange. Moreover, the unidentified peaks in the XRD spectra of KAs 1, 13, and 14 were repeatable, but no reported crystal structure prototype could be found for this phase. Thus, we consider this boron-rich phase, $\mathrm{Ce}_{13} \mathrm{Fe}_{x} \mathrm{Co}_{y} \mathrm{~B}_{45}(32 \leq x \leq 39$, $3 \leq y \leq 10)$, as a new quaternary solid solution in the Ce-Fe-Co-B system at $900{ }^{\circ} \mathrm{C}$.

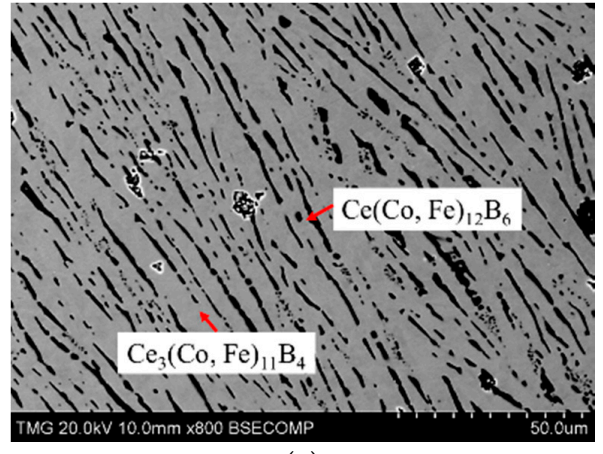

(a)

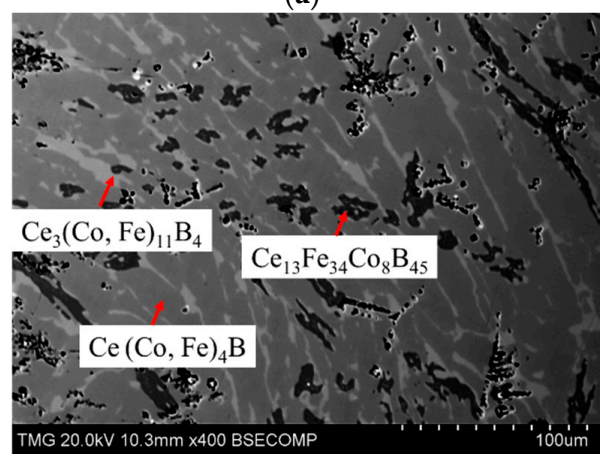

(c)

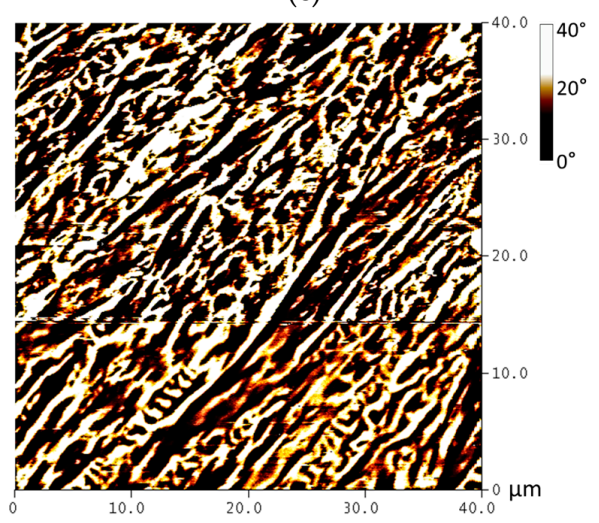

(e)

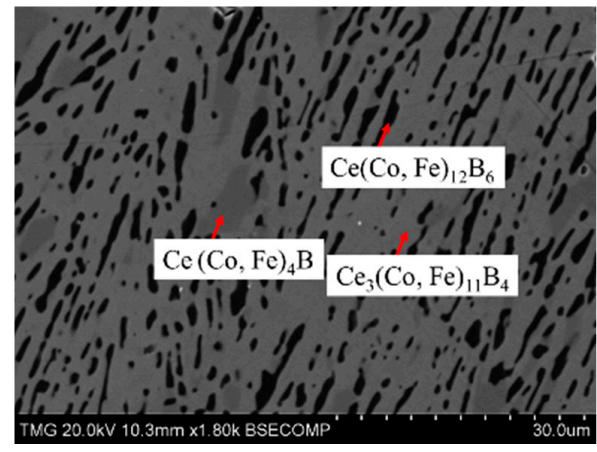

(b)

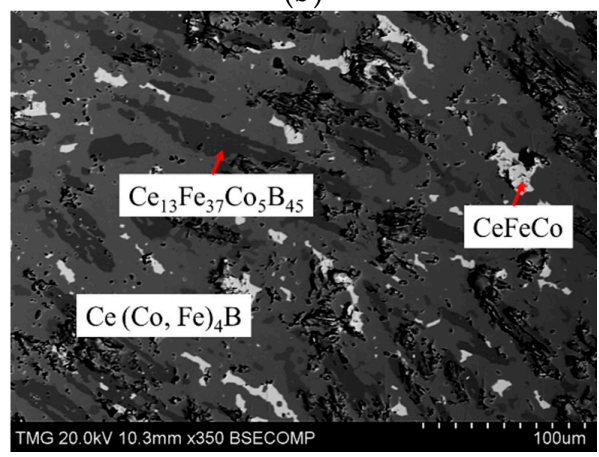

(d)

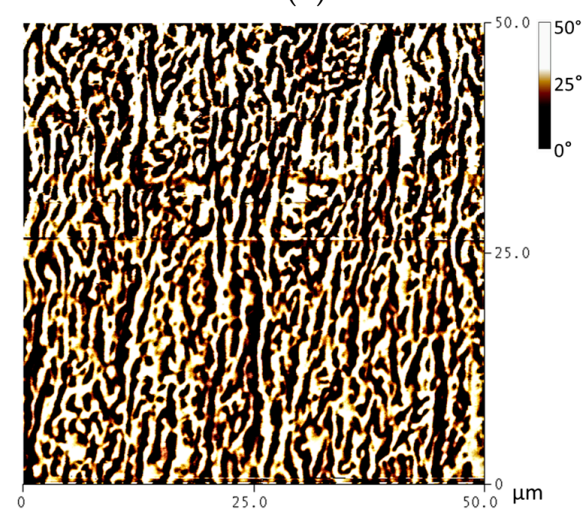

(f)

Figure 20. Cont. 


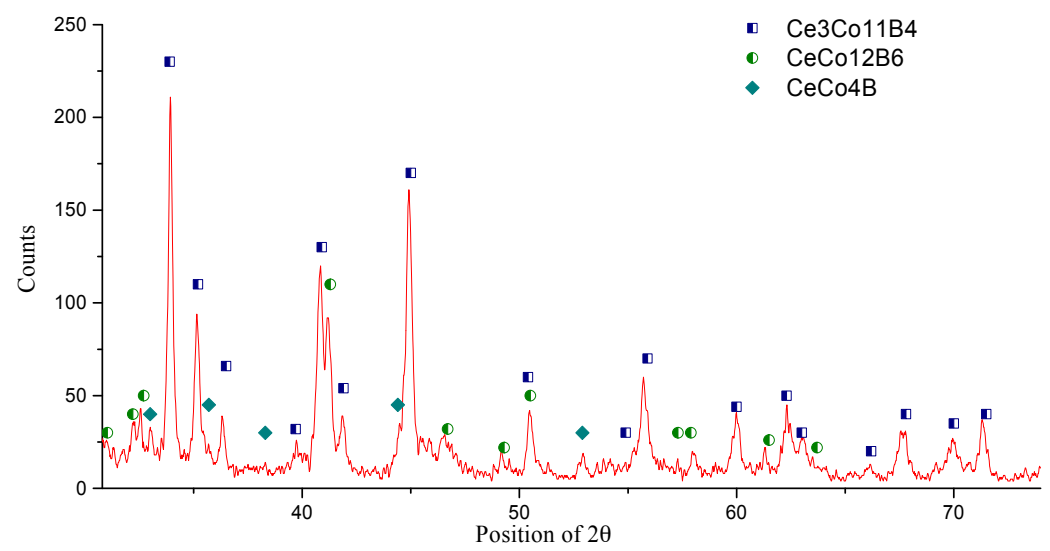

(g)

Figure 20. (a) BSE image of KA 11; (b) BSE image of KA 12; (c) BSE image of KA 13; (d) BSE image of KA 14; (e) MFM image of KA 11; (f) MFM image of KA 12; (g) XRD spectrum of KA 12.

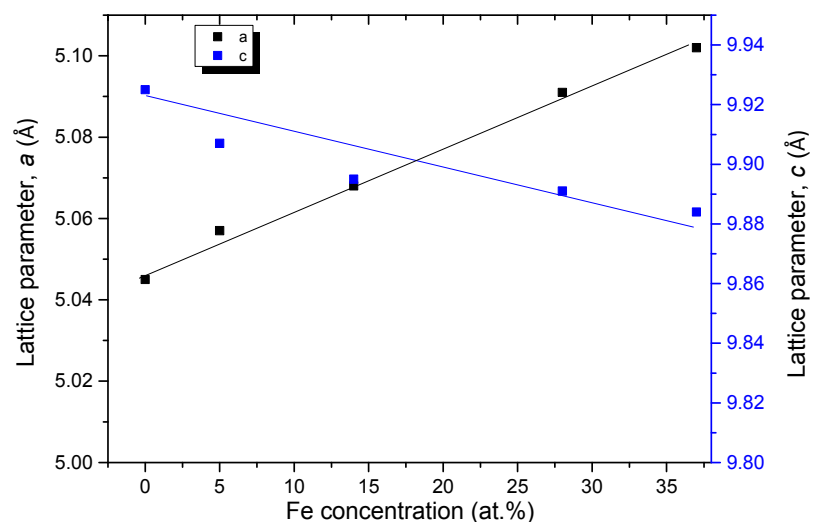

(a)

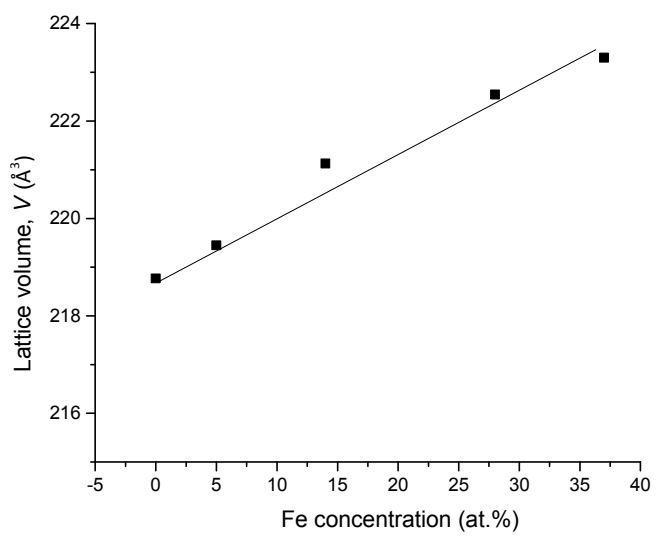

(b)

Figure 21. Cell parameters $a$ and $c(\mathbf{a})$ and lattice volume $V(\mathbf{b})$ with Co concentration for the $\mathrm{Ce}_{3}(\mathrm{Co}, \mathrm{Fe})_{11} \mathrm{~B}_{4}$ from KAs 10-13.

The experimental results of KAs 9-15 are summarized in Figure 22a. Solid solubilities of magnetic $\mathrm{Ce}_{3}(\mathrm{Co}, \mathrm{Fe})_{11} \mathrm{~B}_{4}$ and non-magnetic $\mathrm{Ce}(\mathrm{Co}, \mathrm{Fe})_{12} \mathrm{~B}_{6}$ were first measured by diffusion couples as 23 at. \% $\mathrm{Fe}$ and 18 at. \% Fe, respectively. During the key alloy study, it has been proven that these two phases further extended into this system. And the solubility limits were measured as 46 at. \% Fe and 37 at. \% $\mathrm{Fe}$, respectively. They can be presented as $\mathrm{CeCo}_{12-x} \mathrm{Fe}_{x} \mathrm{~B}_{6}(0.76 \leq x \leq 8.74)$ and $\mathrm{Ce}_{3} \mathrm{Co}_{11-x} \mathrm{Fe}_{x} \mathrm{~B}_{4}$ $(0.9 \leq x \leq 5.04)$, as illustrated in Figure 22a. Two pseudo ternary sections at 6 at. \% and 16 at. \% Ce were used to demonstrate the locations of $\mathrm{Ce}(\mathrm{Co}, \mathrm{Fe})_{12} \mathrm{~B}_{6}$ and $\mathrm{Ce}_{3}(\mathrm{Co}, \mathrm{Fe})_{11} \mathrm{~B}_{4}$, respectively, in Figure 22b,c. In Figure 22d, solid lines are the phase equilibria determined from key alloys, and dotted lines indicate the possible phase equilibria of detected phases. 


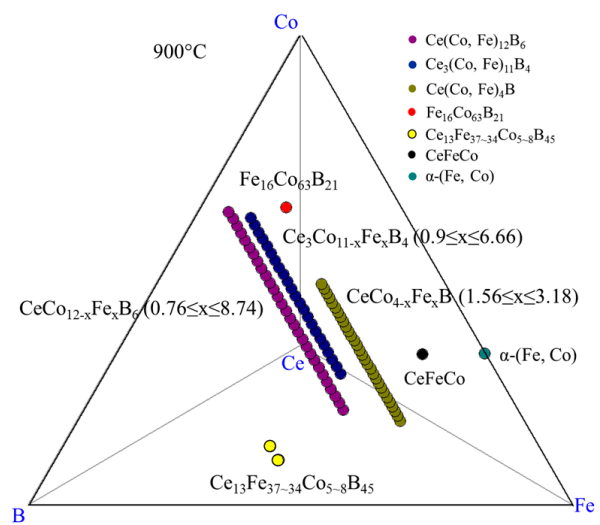

(a)

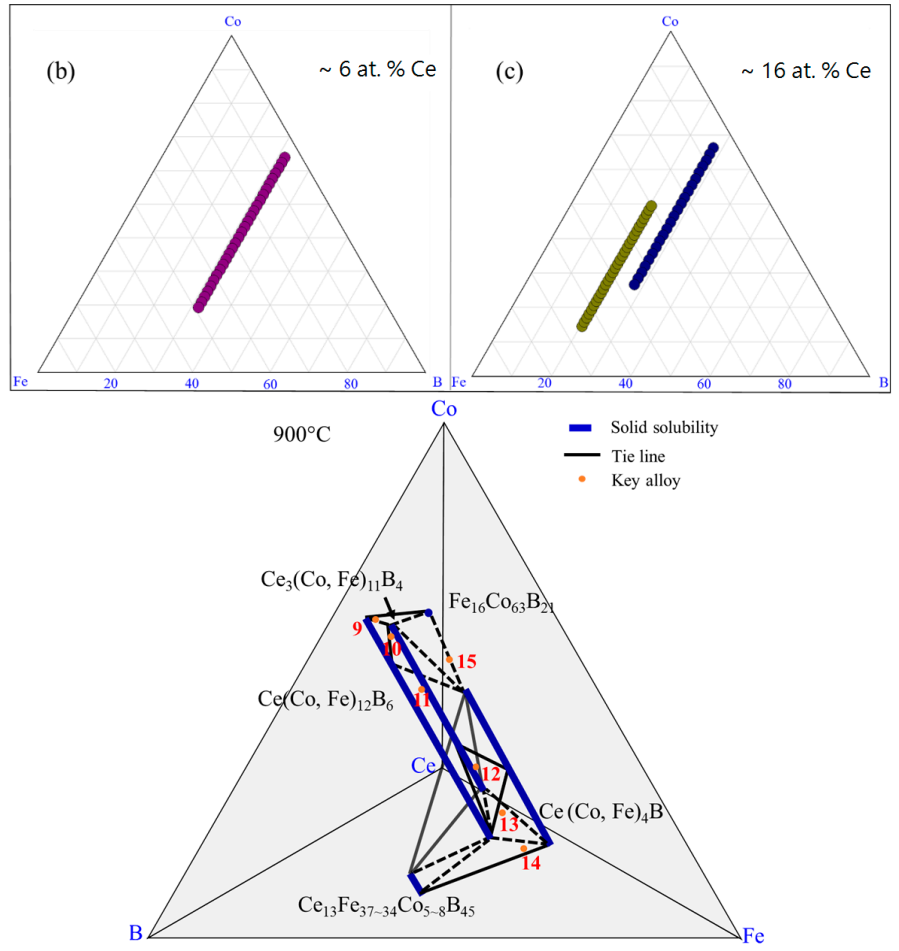

(d)

Figure 22. Homogeneity ranges of $\mathrm{Ce}_{3}(\mathrm{Co}, \mathrm{Fe}){ }_{11} \mathrm{~B}_{4}$ and $\mathrm{Ce}(\mathrm{Co}, \mathrm{Fe}){ }_{12} \mathrm{~B}_{6}$ obtained from key alloys: (a) $3 \mathrm{D}$ presentation of the experimental results; (b) pseudo ternary section at $\sim 6$ at. \% Ce; (c) pseudo ternary section at $\sim 16$ at. $\%$ Ce; (d) phase relations obtained from the key alloys.

Combining the results which were obtained from the diffusion couples with those attained from the key alloys, the phases which were detected in the Ce-Fe-Co-B system in the Fe-Co rich region at $900{ }^{\circ} \mathrm{C}$ were plotted in Figure 23a. Seven three-phase equilibria were established as: $\alpha-(\mathrm{Fe}, \mathrm{Co}) / \mathrm{Ce}_{2}(\mathrm{Fe}, \mathrm{Co})_{14} \mathrm{~B} / \mathrm{Ce}_{2}(\mathrm{Fe}, \mathrm{Co})_{17} ; \mathrm{Ce}_{2}(\mathrm{Fe}, \mathrm{Co})_{14} \mathrm{~B} / \mathrm{Ce}(\mathrm{Co}, \mathrm{Fe})_{4} \mathrm{~B} / \mathrm{CeFeCo}$; $\mathrm{Ce}_{2}(\mathrm{Fe}, \mathrm{Co})_{17} / \mathrm{Ce}(\mathrm{Co}, \mathrm{Fe})_{4} \mathrm{~B} / \alpha-(\mathrm{Fe}, \mathrm{Co}) ; \mathrm{Ce}_{3}(\mathrm{Co}, \mathrm{Fe})_{11} \mathrm{~B}_{4} / \mathrm{Ce}(\mathrm{Co}, \mathrm{Fe})_{12} \mathrm{~B}_{6} / \mathrm{Ce}(\mathrm{Co}, \mathrm{Fe})_{4} \mathrm{~B} ; \mathrm{Ce}_{3}(\mathrm{Co}, \mathrm{Fe})_{11} \mathrm{~B}_{4} /$ $\mathrm{Ce}(\mathrm{Co}, \mathrm{Fe})_{12} \mathrm{~B}_{6} / \alpha-(\mathrm{Fe}, \mathrm{Co}) ; \mathrm{Ce}_{3}(\mathrm{Co}, \mathrm{Fe})_{11} \mathrm{~B}_{4} / \mathrm{Ce}(\mathrm{Co}, \mathrm{Fe})_{4} \mathrm{~B} / \mathrm{Ce}_{13} \mathrm{Fe}_{34} \mathrm{Co}_{8} \mathrm{~B}_{45}$, and $\mathrm{Ce}_{3}(\mathrm{Co}, \mathrm{Fe})_{11} \mathrm{~B}_{4} /$ $\mathrm{Ce}(\mathrm{Co}, \mathrm{Fe})_{4} \mathrm{~B} / \alpha-(\mathrm{Fe}, \mathrm{Co})$. The phase relations of the $\mathrm{Ce}-\mathrm{Fe}-\mathrm{Co}-\mathrm{B}$ system in the Fe-rich corner at $900{ }^{\circ} \mathrm{C}$ were plotted, as shown in Figure 23f. Solid lines are the tie-lines determined in this study and dotted lines represent the possible phase relations. Among those detected phases, $\mathrm{Ce}_{2}(\mathrm{Fe}, \mathrm{Co})_{14} \mathrm{~B}$, $\mathrm{Ce}(\mathrm{Co}, \mathrm{Fe})_{4} \mathrm{~B}$, and $\mathrm{Ce}_{3}(\mathrm{Co}, \mathrm{Fe})_{11} \mathrm{~B}_{4}$ were magnetic phases in this system, which was proven by the MFM study. Also, $\mathrm{Ce}(\mathrm{Co}, \mathrm{Fe})_{12} \mathrm{~B}_{6}$ was identified as non-magnetic. The phases formed in the $\mathrm{Fe}-\mathrm{Co}-\mathrm{Ce}$ system are plotted in the triangle, as shown in Figure 23a. Three pseudo ternary sections at around 
6 at. $\%, 12$ at. $\%$ and 16 at. $\%$ Ce were constructed to demonstrate the locations and phase relations of $\mathrm{Ce}(\mathrm{Co}, \mathrm{Fe})_{12} \mathrm{~B}_{6}, \mathrm{Ce}_{2}(\mathrm{Fe}, \mathrm{Co})_{14} \mathrm{~B}, \mathrm{Ce}(\mathrm{Co}, \mathrm{Fe})_{4} \mathrm{~B}$, and $\mathrm{Ce}_{3}(\mathrm{Co}, \mathrm{Fe})_{11} \mathrm{~B}_{4}$.

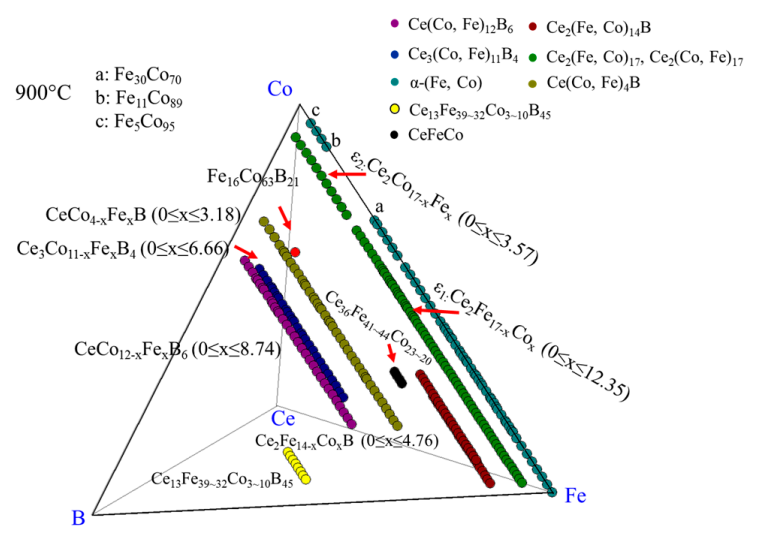

(a)

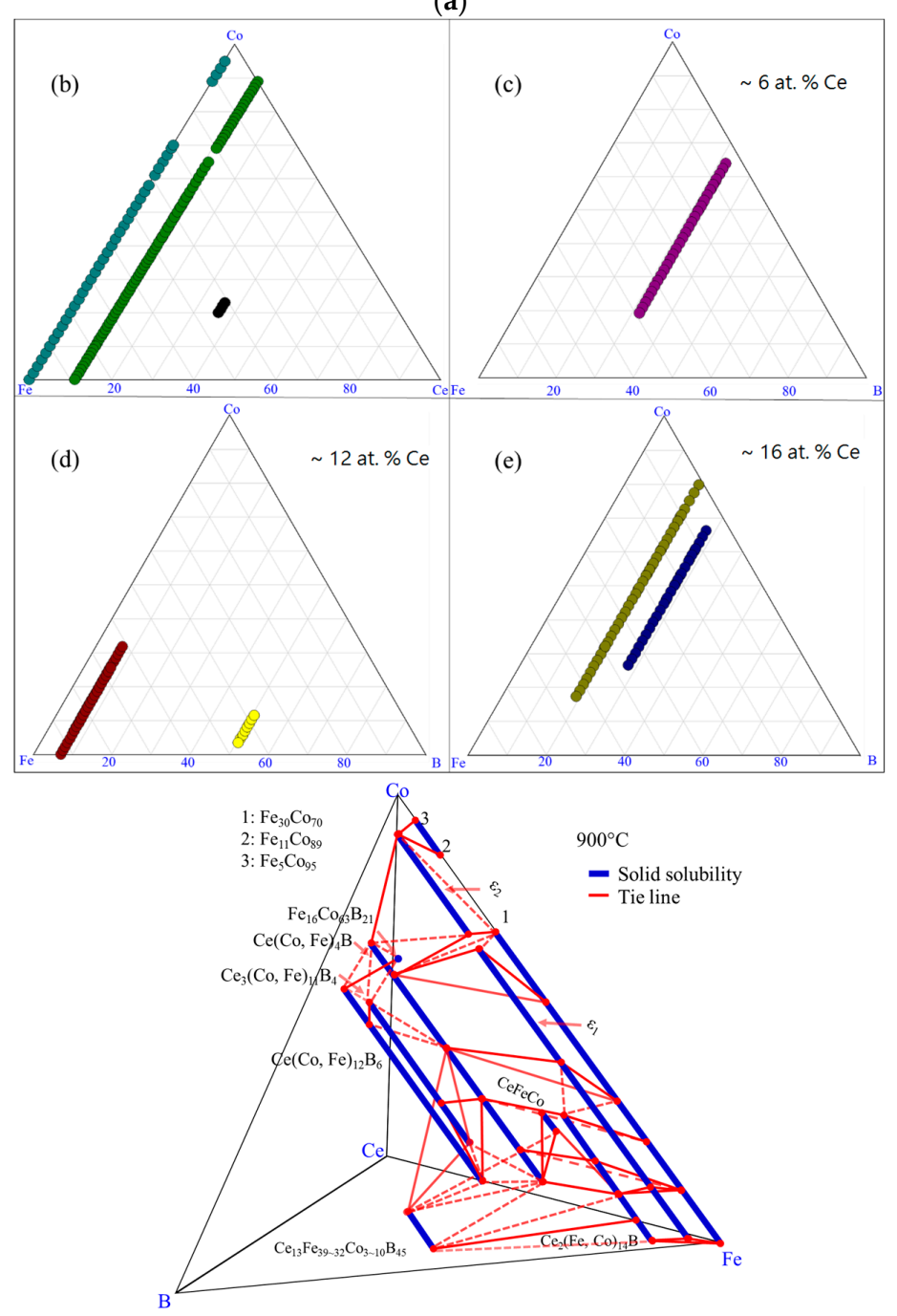

(f)

Figure 23. Combined experimental results of diffusion couples and key alloys in the Ce-Fe-Co-B system at $900{ }^{\circ} \mathrm{C}$ : (a) 3D presentation of the experimental results; (b) Fe-Ce-Co ternary system; (c) pseudo ternary section at $\sim 6$ at. $\% \mathrm{Ce}$; (d) pseudo ternary section at $\sim 12$ at. $\% \mathrm{Ce}$; (e) pseudo ternary section at $\sim 16$ at. \% Ce; (f) phase relations in the Fe-rich region of the Ce-Fe-Co-B system at $900{ }^{\circ} \mathrm{C}$. 


\section{Conclusions}

A high-throughput screening method was found to be effective in studying the phase equilibria in the $\mathrm{Ce}-\mathrm{Fe}-\mathrm{Co}-\mathrm{B}$ system while exploring potential magnetic phases. Phase equilibria and homogeneity ranges have been determined in the $\mathrm{Fe}-\mathrm{Co}$ rich side of the $\mathrm{Ce}-\mathrm{Fe}-\mathrm{Co}-\mathrm{B}$ system at $900^{\circ} \mathrm{C}$. Three magnetic phases are observed which are presented as $\mathrm{Ce}_{2} \mathrm{Fe}_{14-x} \mathrm{Co}_{x} \mathrm{~B}(0 \leq x \leq 4.76), \mathrm{CeCo}_{4-x} \mathrm{Fe}_{x} \mathrm{~B}(0 \leq x \leq 3.18)$, and $\mathrm{Ce}_{3} \mathrm{Co}_{11-x} \mathrm{Fe}_{x} \mathrm{~B}_{4}(0 \leq x \leq 6.66)$. $\mathrm{Ce}_{2}(\mathrm{Fe}, \mathrm{Co})_{14} \mathrm{~B}$ exhibited stronger magnetic interaction than $\mathrm{Ce}(\mathrm{Co}, \mathrm{Fe})_{4} \mathrm{~B}$ and $\mathrm{Ce}_{3}(\mathrm{Co}, \mathrm{Fe})_{11} \mathrm{~B}_{4}$ during the MFM analysis. Moreover, a non-magnetic $\mathrm{CeCo}_{12-} \mathrm{Fe}_{x} \mathrm{~B}_{6}$ $(0 \leq x \leq 8.74)$ was found to form in this system at $900{ }^{\circ} \mathrm{C}$. A boron-rich solid solution with $\mathrm{Ce}_{13} \mathrm{Fe}_{x} \mathrm{Co}_{y} \mathrm{~B}_{45}(32 \leq x \leq 39,3 \leq y \leq 10)$ chemical composition was observed in this quaternary system. The crystal structure of this phase has not been reported in the literature. In addition, two solid solutions $\varepsilon_{1}\left(\mathrm{Ce}_{2} \mathrm{Fe}_{17-x} \mathrm{Co}_{x}(0 \leq x \leq 12.35)\right)$ and $\varepsilon_{2}\left(\mathrm{Ce}_{2} \mathrm{Co}_{17-x} \mathrm{Fe}_{x}(0 \leq x \leq 3.57)\right)$ were found to form between $\mathrm{Ce}_{2} \mathrm{Fe}_{17}$ and $\mathrm{Ce}_{2} \mathrm{Co}_{17}$ in the Ce-Fe-Co ternary system at $900{ }^{\circ} \mathrm{C}$.

Acknowledgments: Financial support from General Motors of Canada Ltd., and the Natural Sciences and Engineering Research Council of Canada through the CRD grant program is gratefully acknowledged. The authors thank Frederick Pinkerton for the useful discussions on the methodology of this work. The authors also would like to thank TMG members, especially Ahmad Mostafa for his help and Kayode Orimoloye for his support during the experimental work.

Author Contributions: M.M. initiated the project. M.M., D.K. and T.W. conceived and designed the experiments. T.W. carried out the experiments. M.M., D.K. and T.W. interpreted the results. M.M. and T.W. wrote the manuscript.

Conflicts of Interest: The authors declare no conflict of interest.

\section{References}

1. Buschow, K.H.J. New permanent magnet materials. Mater. Sci. Rep. 1986, 1, 1-64. [CrossRef]

2. Herbst, J.F.; Meyer, M.S.; Pinkerton, F.E. Magnetic hardening of $\mathrm{Ce}_{2} \mathrm{Fe}_{14}$ B. J. Appl. Phys. 2012, 111, 1-3. [CrossRef]

3. Skoug, E.J.; Meyer, M.S.; Pinkerton, F.E.; Tessema, M.M.; Haddad, D.; Herbst, J.F. Crystal structure and magnetic properties of $\mathrm{Ce}_{2} \mathrm{Fe}_{14-x} \mathrm{Co}_{x} \mathrm{~B}$ alloys. J. Alloys Compd. 2013, 574, 552-555. [CrossRef]

4. Bilonizhko, N.S.; Yu, B.; Kuz'ma, N.S. Ce-Fe-B system. Izv. Akad. Nauk SSSR Neorg. Mater. 1972, 8, 183-184.

5. Dub, O.M.; Kuz'ma, Y.B. Ternary borides with the $\mathrm{Nd}_{2} \mathrm{Fe}_{14}$ B structure. Soviet Powder Metall. Met. Ceram. 1986, 25, 572-575.

6. Bezinge, A.; Braun, H.F.; Muller, J.; Yvon, K. Tetragonal rare earth $(\mathrm{R})$ iron borides, $\mathrm{R}_{1+x} \mathrm{Fe}_{4} \mathrm{~B}_{4}(x \approx 0.1)$ with incommensurate rare earth and iron substructures. Solid State Commun. 1985, 55, 131-135. [CrossRef]

7. Dub, O.M.; Chaban, N.F.; Kuz'ma, Y.B. New borides of $\operatorname{Pr}_{5-x} \mathrm{Co}_{2+x} \mathrm{~B}_{6}$-type structure. J. Less-Common Met. 1986, 117, 297-303. [CrossRef]

8. Raghavan, V.; Raynor, G.V.; Rivlin, V.G. Phase Diagrams of Ternary Iron Alloys; ASM International: Materials Park, OH, USA, 1987; Part 3; pp. 297-300.

9. Rogl, P.; Schuster, J.C.; Nowotny, H. Phase equilibrium and compound formation in Fe-M(metal)-BX(non-metal) systems. In Boron in Steel Proceeding of the International Symposium; Metallurgical Society of AIME: Milwaukee, WI, USA, 1979; pp. 33-43.

10. Pradelli, G.; Gianoglio, C.; Quadrini, E. The Co-Fe-B system in the presence of liquid. Met. Ital. 1981, 73, 351-355.

11. Van Loo, F.J.J; van Beek, J.A. Reactions and phase relations in the Fe-Ni-B and Fe-Co-B dystems. Z. Metallkd. $1989,80,245-250$.

12. Liu, Y.Q.; Zhao, X.S.; Yang, J.; Shen, J.Y. Thermodynamic optimization of the Boron-Cobalt-Iron system. J. Alloys Compd. 2011, 509, 4805-4810. [CrossRef]

13. Bilonizhko, H.C.; Kuz'ma, N.S.; Yu, B. Cerium-cobalt-boron system. Izv. Akad. Nauk SSSR Neorg. Mater. 1974, 10, 265-269.

14. Kuz'ma, Y.B.; Bilonizhko, N.S.; Mykhalenko, S.I.; Stepanchikova, G.F.; Chaban, N.F. The interaction of transition and rare earth metals with boron. J. Less-Common Met. 1979, 67, 51-57. [CrossRef]

15. Jurczyk, M. Crystallographic and magnetic characteristics of the $\mathrm{Ce}_{3} \mathrm{Co}_{20} \mathrm{~B}$ compound. Phys. Status Solidi A 1987, 100, K173-K176. [CrossRef] 
16. Kuz'ma, Y.B.; Chernyak, G.V.; Chaban, N.F. New borides of rare-earth metals with the structure of $\operatorname{SrNi}_{12} \mathrm{~B}_{6}$ type. Dopov. Akad. Nauk Ukr. RSR Ser. A 1981, 12-80.

17. Dub, O.M.; Skolozdra, R.V.; Kuz'ma, Y.B.; Dubenko, N.S. Magnetic and electrical parameters of ternary rare-earth borides containing cobalt and nickel. Inorg. Mater. 1990, 26, 1034-1037.

18. Critchley, J.K. Low melting point alloys of cerium with iron, cobalt and plutonium. U.K. At. Energy Auth. Harwell Lab. Memo AERE-M 1959, 488, 1-7.

19. ASM Alloy Phased Diagram Database. Available online: http://www1.asminternational.org/AsmEnterprise/ APD/BrowseAPD.aspx (accessed on 3 November 2015).

20. Su, X.; Zhang, W.J.; Du, Z.M. A thermodynamic modelling of the Co-Ce system. J. Alloys Compd. 1998, 267, 121-127. [CrossRef]

21. Mansey, R.C.; Raynor, G.V.; Harris, I.R. Rare-earth intermediate phases VI. Pseudo-binary systems between cubic laves phases formed by rare-earth metals with iron, cobalt, nickel, aluminum and rhodium. J. Less-Common Met. 1968, 14, 337-347. [CrossRef]

22. Harris, I.R.; Longworth, G. X-ray and Mössbauer studies of the pseudo-binary system $\mathrm{Ce}\left(\mathrm{Fe}_{1-x} \mathrm{Ni}_{x}\right)_{2}$. J. Less-Common Met. 1976, 45, 63-77. [CrossRef]

23. Longworth, G.; Harris, I.R. Mössbauer effect study of the pseudo-binary system $\mathrm{Ce}\left(\mathrm{Fe}_{1-x} \mathrm{Co}_{x}\right)_{2}$. J. Less-Common Met. 1975, 41, 175-185. [CrossRef]

24. Putz, H.; Brandenburg, K. Pearson's Crystal Data, Crystal Structure Database for Inorganic Compounds, CD-ROM Software Version 1.3; ASM International: Materials Park, OH, USA, 2007.

25. Wang, T.; Kevorkov, D.; Mostafa, A.; Medraj, M. Experimental investigation of the phase equilibria in the Al-Mn-Zn system at $400{ }^{\circ} \mathrm{C}$. J. Mater. 2014, 2014, 451587. [CrossRef]

26. X'Pert HighScore Plus, version 2.2b (2.2.2); PANalytical: Almelo, The Netherlands, 2006.

27. Hartmann, U. Magnetic Force Microscopy. Annu. Rev. Mater. Sci. 1999, 29, 53-87. [CrossRef]

28. Fujii, H.; Satyanarayana, M.V.; Wallace, W.E. Magnetic and crystallographic properties of substituted $\mathrm{Ce}_{2} \mathrm{Co}_{17-x} \mathrm{~T}_{x}$ compounds (T = Ti, V, Cr, Mn, Fe, Cu, Zr, and Hf). J. Appl. Phys. 1982, 53, 2371-2373. [CrossRef]

29. Yang, L.; Dayal, K. Effect of lattice orientation, surface modulation, and applied fields on free-surface domain microstructure in ferroelectrics. Acta Mater. 2011, 59, 6594-6603. [CrossRef]

30. Denton, A.R.; Ashcroft, N.W. Vegard's Law. Phys. Rev. A 1991, 43, 3161-3164. [CrossRef] [PubMed] 